\title{
WINNER OR LOSER? (EN TORNO AL «PARADIGMA DEL ÉXITO»)
}

Héctor Lerma Jasso

Hipóloco me engendró, de él tengo mi prosapia. Cuando me mandó a Troya me advirtió con insistencia que luchara siempre por alcanzar el precio de la más alta virtud humana

y que fuera siempre, entre todos, el mejor.

Homero, Iliada, XI.

La triste condición de quien se considera el mejor en cualquier sentido, es comprobar que siempre hay alguien que lo supera en eso mismo. Santiago Hernández.

\section{RESUMEN}

Los hombres de todas las épocas han buscado, en mayor o menor medida, con mayor o menor claridad, llevar a buen puerto su existencia: "triunfar en la vida".

Dos son los obstáculos que pueden dificultar este objetivo: el fracaso (no realizar aquello que se perseguía) y/o la frustración (el abandono ante el ideal pretendido). Por eso, el camino hacia la plenitud está sembrado de dolor.

El éxito y el fracaso son siempre relativos. El hombre maduro sabrá dar jerarquía a las cosas y, sobre todo, sabrá aceptarse independientemente de la realización o no de aquello que ha perseguido porque conoce que la vida es, también, apertura flexible -y sonriente- ante los ideales y ante la vía que nos encamina a ellos.

La plenitud existencial exige también sabiduría: el sendero humano está repleto de limitaciones personales y ajenas; los fracasos y el dolor son vías alternas -y en ocasiones, las más exigentes y sólidas- para la edificación del proyecto vital. 


\section{¡AH, QUÉ TIEMPOS!}

¿Qué extraño resultaría que, de pronto, alguno de nuestros amables lectores -por muy winner que sea- ciñera su cabeza con una diadema de hierbas simbólicas: olivo, laurel (o cilantro y perejil, menos simbólicas pero más a mano) y, portando una oveja entre sus brazos, se lanzara a recorrer esas calles de Dios, tratando de suscitar, por parte de los desconcertados transeúntes, aplausos y vítores de admiración hacia su persona, mientras avanza, con paso solemne y actitud hierática, hacia algún templo vecino, dispuesto a descuartizar e incinerar al inocente animalito!

No. Nadie, en la actualidad, se atrevería a actuar así. Primero, por un mínimo de sentido de la realidad y del ridículo. Segundo, porque la multitud-que suele ser muy cruel-, le gritaría cosas horribles (impropias de ser referidas aquí). Y, tercero, por temor a que le quiten la corona y le ciñan, en cambio, una austera camisa de fuerza y, en vez de al templo, lo remitan al centro de rehabilitación mental más cercano.

Sin embargo, en otras épocas, era habitual que ciertos personajes - pocos, por fortuna- se sometieran o fueran sometidos a rituales semejantes, llenos de boato y esplendor. Claro que eran otros tiempos, otras costumbres (¡O témpora! ¡O mores!, como entonces se decía).

Por supuesto que hay, aún en nuestros días, muchas personas - "ganadoras" o no- que desfilan (políticos, militares, deportistas, escolares, manifestantes de esto o de lo otro...). Hay, en menor número, personas que reciben el honor de ser coronadas (soberanos, misses", "flores del ejido"...). Y por fortuna, nadie, o casi nadie, en su sano juicio, se atreve a celebrar rituales cruentos, a no ser clandestinamente.

\section{¡RECUERDA QUE ERES MORTAL!}

En cambio, en la Roma pagana, por ejemplo, la ovatio u ovación, antes de consistir en la serie de aplausos ruidosos y 
alegres tributados por una multitud, tal como la entendemos ahora, consistió en un "rito menor" con el que se honraba a algún ciudadano conspicuo o a algún militar, atleta o poeta victorioso. Parece ser que, en su sentido más remoto, la ovación (de ovis: oveja; y de ovare: alegrarse, estar contento) consistía en el alto honor de sacrificar, de acuerdo con una tradición tan antigua como universal, una oveja tierna, inmaculada, sin defecto, como agradecimiento por haber logrado una hazaña exitosa.

El héroe, merecedor de los honores de la ovación, se dirigía hacia algún templo principal. Pronunciaba ciertos votos, alabanzas y juramentos. Y, en los altares de alguno de los dioses del complejo panteón romano (Júpiter, Minerva, Juno, Vesta, Marte, Diana...), procedía a matar e incinerar, hasta la consumación total, al animal elegido (podía ser también un cerdo o un toro). Toda esta batahola iba acompañada de grandes fiestas abiertas a la plebe, himnos, panegíricos, juegos, libaciones de hidromiel y cerveza fresca.

Otra ceremonia honorífica era la processio: el desfile glorioso del "ganador" para celebrar la prominencia de su nobleza y sus hazañas. Este prohombre, vestido con toga púrpura esmaltada de estrellas, sobre un carruaje de oro tirado por cuatro caballos blancos enjaezados, recorría las principales calles de la ciudad, recibiendo loas, vítores o gritos de aclamación, motivados por la admiración -o por la manipulación de la emocionalidad- de la masa humana.

El numeroso cortejo, integrado por subalternos, familiares, amigos y antagonistas derrotados, era acompañado por charangas de flautas, trompetas, tamboriles y panderos que tocaban fanfarrias y marchas militares. El solemne día de la processio, era considerado día festivo (diaes fasto) para todo el pueblo, con su asueto correspondiente.

Fue precisamente el día que Julio César, convertido en flami dial (sacerdote de Júpiter), hizo su entrada y desfile glorioso por la urbe romana, cuando mandó enarbolar, 
entre otros ornamentos triunfales, el famoso pendón que rezaba: jveni, vidi, vinci!

Otra ceremonia era la coronatio: coronación. Las sienes del "ganador": alma selecta nimbada de gloria, eran coronadas con una guirnalda de olivo y laurel, simbolizando el honor y la fama. En un principio, la corona era de ramas auténticas; más tarde, las hojas eran de láminas de oro o plata, resultando demasiado pesada. Era preciso, entonces, que un servidor acompañara al homenajeado -abrumado, sin duda, por el peso de los arreos y de la tiara, no por la modestia-, a fin de ayudarle a sostener el peso de la corona sobre su gloriosa testa mientras que, a fin de moverlo a recato y humildad, le leía al oído una relación de sus pecados, al tiempo que le susurraba: ¡Recuerda que eres mortal; recuerda que eres mortal!

\section{¡ARRIBA EL TRIUNFADOR! ¡HURRA EL GANADOR!}

Estas celebraciones podían llegar a más. Cuando algún "ganador" mostraba de manera preeminente sus cualidades y proezas, era merecedor del "triple reconocimiento" (processio,

ovatio y coronatio); esto constituía el tri-umphus, o triunfo: triple homenaje o "rito mayor".

Una vez concedido el triunfo por el Senado, el triunfador (digamos, el winner) recibía todos los honores humanos y divinos. Entre las aclamaciones de la plebe (impropiamente los losers) y bajo una lluvia de flores, entraba en cuadriga, vestido y maquillado como el dios Júpiter, con manto púrpura bordado en oro, corona también de oro y un rayo dorado en la mano diestra. Su paso era anunciado por trompetas y precedido por los lictores con las fasces y seguido por magistrados, guerreros, familiares, amigos y público en general. El cortejo pasaba bajo los arcos triunfales en su tránsito del campo de Marte al Capitolio y desde ahí al templo de Júpiter, donde el triunfador ofrecía sus laureles y corona de oro en señal de agradecimiento. Finalmente ofrecía los honores de la ovación, o sacrificio solemne, en nombre del pueblo. 
(Si sacrificaba tres animales - un cerdo (sus), una oveja (ovis) y un toro (taurus)-, se llamaba suovetaurilia).

El Senado y el pueblo romano (SPQR: Senatus Populusque

Romanus) le otorgaban al triunfador (vir egregius) diversos títulos: héroe, patricio, feliz, hijo de los dioses, ciudadano de prez y pro... Al fin, todo el fastuoso aparato triunfal, ebrio de gloria, vino y cerveza, reposaba en los atrios del templo de Jano Quirino mientras coreaba: ¡Io triumphe! jIo triumphe! (Esto es: Hurrab the winner!: ¡Hurra al triunfador!).

\section{¡APLAUDAN, PUES! ¡APLAUDAN!}

Para el homenajeado, las mieles del triunfo significaban gloria, genio, riqueza e influencia, además de medallas, trofeos y monumentos ( $\sin$ faltar las indecorosas adulaciones, vergonzosas lisonjas y rencorosas envidias). Su esclarecido nombre era inscrito en el elenco de viris illustribus (por ejemplo, el de Suetonio: una especie de Forbes, o de Who's who de la época) y quedaba esculpido en innumerables mármoles, columnas, frontispicios y monedas.

Desde luego que la solemnidad, pompa y circunstancia que rodeaban al recorrido triunfal tenía mucho de carnavalesco y más aún de inhumano. Los rivales vencidos (propiamente los losers) -reyes, generales, sus soldados, familias y esclavos- formando parte del cortejo como rehenes y cautivos, desfilaban encadenados de pies y manos al cuello, mientras eran insultados y apedreados por el populacho y, a rastras, eran conducidos a la cárcel Mamertina, donde eran ejecutados.

No raras veces la "autoestima" del ilustre homenajeado -para decirlo con terminología moderna- se disparaba de tal manera, hasta dejarlo instalado fuera y por encima de los simples mortales. Ése era el privilegio del triunfador: ser el número uno; gozar del reconocimiento público; destacar entre los demás. Éstos dejaban de ser sus "semejantes" para convertirse en súbditos; la admiración se convertía en sometimiento; la lealtad se trocaba en pleitesía; el respeto devenía en 
engreimiento. Fue Augusto -por poner un ejemplo-, el emperador romano que, en su lecho de muerte, convocó a sus amigos para preguntarles acerca del éxito de su gestión y, como la respuesta fuese positiva y entusiasta, les dijo: PPlaudite! ¡Plaudite! (“iAplaudan, aplaudan, pues!»)... iy se murió!

\section{LA MUSA QUE PRODUCE DINERO}

El triunfo era la apoteosis (del griego apo: volver, transformar en; y theos: dios): que concedía al héroe la categoría de dios. Era el éxito (de exitus: acción de salir; salir de lo común, sobresalir); el endiosamiento que convertía al hombre en egregio (de ex: fuera, y grex, gregis : grey, rebaño, reunión) y su nombre era añadido al amplio elenco de dioses.

No era raro que así, ubicado entre -o por encima de- los dioses, el triunfador, harto de saludar, sonreír y soportar las quejas, demandas y miserias de súbditos y aduladores, terminara por odiar a la plebe que lo había encumbrado y vitoreado.

Entre miles de ejemplos, baste recordar que Suetonio, en su libro los Doce Césares (De vita Caesarum), cuenta que cierto día el emperador triunfador Calígula -cuya triste fama quedó fincada en su consigna: iNo me importa que me odien con tal de que me teman!-, se colocó por burla al lado de la estatua de Júpiter, y preguntó al actor Apeles cuál de los dos le parecía más grande, y como éste vacilase en contestar, lo hizo azotar en el acto, con tal intensidad que sus gritos y lamentos deleitasen a la ciudad entera. Éste mismo emperador, según decía, disfrutaba con las lisonjas del populacho romano, aunque secretamente lo odiaba. Llegó a decir que: ¡Ojalá tuviese una sola cabeza el pueblo romano, para cortarla de un solo tajo!

También en nuestros días tenemos pruebas abundantes de este paradójico fenómeno. Son muchos los casos de líderes, artistas, gobernantes, atletas o profesionales triunfadores que, a pesar de su facha sonriente y dulce, y no obstante sus vehementes protestas de amor al "respetable público", al "amado pueblo", o al "cliente que es lo primero 
y siempre tiene la razón", secretamente lo desprecian ${ }^{1}$. Y lo notable es que, quizá como revancha, este fenómeno es de ida y vuelta: los fans (que viene de fanático y quiere decir: idólatra, fiel, entusiasta...; pero también significa intransigente, intolerante, obcecado...) se convierten, de dóciles seguidores, en crueles tiranos que agravian a sus ídolos y, con frecuencia, se complacen en darles la espalda y despreciarlos hasta verlos humillados y caídos en desgracia ${ }^{2}$.

\section{¡PAN Y CIRCO!}

Lo anterior explica, dentro de la industria de la diversión, el éxito de programas de radio y televisión, y de publicaciones llenas de "chismes de famosos", o de los realities shows en los que se exhibe, junto a los éxitos más glamorosos y estilos de vida más sofisticados, la intimidad más amarga, los secretos más vergonzosos, las penas más dolorosas y los escándalos más ruinosos de los triunfadores. Triunfos fincados, con frecuencia, sobre el lema: iQue bablen de mí, bien o mal, pero que hablen! ¡Todo sea por la fama, que es dinero! (Que conste que no juzgo, sólo describo).

También en el otro paganismo -el de la Roma imperial antes descrito-, el boato triunfalista fue de triunfo para ciertos

\footnotetext{
${ }^{1}$ Mario Vargas Llosa, al relatar algunos episodios de la vida de un tristemente célebre dictador, describe una de estas situaciones. Y dice que es difícil: "Comprender que tantos millones de personas, machacadas por la propaganda, por la falta de información, embrutecidas por el adoctrinamiento, el aislamiento, despojadas de libre albedrío, de voluntad y hasta de curiosidad por el miedo y la práctica del servilismo y la obsecuencia, llegaran a divinizar a Trujillo. [Éste] les sacó del alma una vocación masoquista, de seres que necesitaban ser escupidos, maltratados, que sintiéndose abyectos se realizaban. [Y es que] de un resentido, siempre se debe esperar lo peor (La fiesta del Chivo., Alfaguara., 1999., pp.75, 76 y 88).

${ }^{2}$ Un ejemplo dramático de este revanchismo, fue el de la reina María Antonieta. Recién llegada a Francia, sin la menor sombra de sospecha de que pasado no mucho tiempo sería condenada a muerte y ejecutada en la guillotina, escribe a su madre, María Teresa de Austria, una carta rebosante de encantadora ingenuidad: "iQué gentiles son los franceses! He sido recibida en Estrasburgo como la hija más amada. Me dedican tantos cumplidos que casi tengo miedo, porque no sé si verdaderamente merezco tantos agasajos".
} 
literatos (como ahora para los medios). Los himnos de alabanza a los dioses, se transformaron en cantos consagrados a la glorificación del supuesto ganador. El hombre -a veces con más ambición que mérito- se convirtió en objeto de los himnos. Tal secularización dio pie a una nueva forma de lucro. El triunfo se convirtió -según lo señala el vardo Simónides de Julis-, en la musa que produce dinero. Dinero para el triunfador y para el rapsoda, creando entre ellos una especie de complicidad o "sociedad de bombos mutuos", tan ruin como lucrativa. (Vulgarmente se dice que: unos suben porque pueden y otros porque se acomodan; o que: unos valen, otros se enchufan).

Y es así como la industria del éxito se convirtió en parte medular de la consigna político-demagógica: panem et circensis (ipan y circo!).

\section{¿A QUÉ VIENE TODO ESTO?}

Todo esto viene a que, en nuestros días, las nociones de éxito, triunfo y conceptos afines, parecen haberse convertido, explícita o implícitamente, en principio, fin y modelo paradigmático de lo que, en amplios sectores de la población mundial, se considera una "buena educación": "formación para el éxito", "pedagogía del éxito", "cantera de triunfadores"... La humanidad entera parece haberse dividido en dos grupos asimétricos: el pequeño y selecto racimo de los "triunfadores" y la extensa masa de los "perdedores". División maniquea que parece exigir de cada individuo una definición radical: winner or loser; y exige, de las instituciones educativas, transformaciones profundas en cuanto a sus objetivos, contenidos y métodos. Después de todo: Los vientos que corren en la sociedad son los mismos que soplan en la escuela ${ }^{3}$.

Ya Lucien Morin advertía que desde que se lanzó el lema publicitario: "Quien se instruye, se enriquece", el hada de la

${ }^{3}$ Ortega y Gasset, José., "Misión de la Universidad", en Revista de Occidente., Madrid., 1968., pp.19-20. 
economia no ha dejado de transformar las calabazas de la educación en carrozas de plata ${ }^{4}$. Esto ha dado lugar a una publicidad que, con frecuencia: engaña la credulidad juvenil con la promesa de un éxito académico, profesional y existencial repentino y de una saludable felicidad, contenidos en el elixir de un saber práctico y útil, accesible a todos.

En efecto: abundan a nuestro alrededor textos, cursos y programas que ofrecen una educación que garantiza el éxito en la vida. Son propuestas que entusiasman, motivan y ayudan porque contienen, a veces, interesantes reflexiones, ingeniosos consejos, llamativas técnicas y orientaciones útiles. Tienen, en muchos casos, la sana intención de despertar el afán de superación, inyectar seguridad, mejorar las disposiciones, abrir horizontes, ampliar la visión... Se multiplican, incluso, nuevas profesiones a este respecto: agente de superación, promotor de triunfadores, convencedor profesional, alentador del éxito, diseñador de imagen, asesor para el éxito, formador de ganadores, expert on couching...

Se ofrecen, como en bandeja, el camino, la clave, la fórmula, los 7 pasos... del éxito. Se impele a reprogramarse, autosuperarse, autoayudarse, llegar a la cumbre, lograr el triunfo, cambiar de actitud, vivir en lo alto... Se ilustra acerca de cómo pensar, comer, vestir, caminar, hablar... como un ganador. Se motiva a salir de la mediocridad de una vez y para siempre, a pronunciarse por el triunfo, a no improvisar el éxito, a no tener miedo a ser feliz... ${ }^{6}$.

\footnotetext{
${ }^{4}$ Lucien Morin., Los charlatanes de la nueva pedagogía., Herder., 1975., p.175. ${ }^{5}$ Ibid., p.116.

${ }^{6}$ Algunas de esas fórmulas sorprenden por su excesiva facilidad, como cuando se dice: triunfe en los negocios, use camisas tal; asegure su éxito en sociedad: luzca un lindo cutis con el jabón equis; aumente su autoestima con la milagrosa faja reductiva tal... En cambio, otras, a pesar de su aparente facilidad, decepcionan al candidato a triunfador (recuérdese que "candidato" viene de candidez), ya que las condiciones que entrañan se asemejan a las impuestas a Perseo en su intento por salir airoso en su empresa (¡cortar, ni más ni menos, la cabeza de la terrible Gorgona!). Necesitaba arrebatar -jasómbrese usted!-: la espada y las sandalias aladas a Hermes; el escudo de bronce bruñido a Atenea, el ojo único a las temibles Grayas; y, lo más desconcertante: portar un zurrón mágico, con la propiedad de amoldarse al tamaño de lo que contenía y un casco que lo haría invisible, astuto y valiente.
} 


\section{RACIONALIDAD TECNOLÓGICA Y EFICACIA TÉCNICA}

Y se ha dado, últimamente, una especie de simbiosis entre el paradigma del éxito y el pragmatismo utilitarista contenido en la idea de la racionalidad tecnificada, racionalidad instrumental, racionalidad funcional, o racionalidad orientada por el objetivo. Según esto, las normas de la verdad, el bien y la justicia son determinadas por la eficacia de ciertas acciones para conseguir los resultados previstos; es decir: por la utilidad.

Así, la verdad no se desprende de la realidad, sino que realidad y verdad son producto la poiesis humana. El hombre -también construcción autopoiética- construye el conocimiento. Las ideas acerca del ser del hombre, del sentido y significado de la vida humana y de las metas de la sociedad, son consideradas como construcciones conceptuales - constructos-del arbitrio humano. Incluso los valores de la religión (trascendental), se ven como "ideologías" construidas por los grupos humanos con propósitos técnico-utilitarios.

La producción de conocimientos es vista como un proceso industrial, en el que consumidores y productores tratan el conocimiento como una mercancía. El conocimiento es producido para venderse y consumirse ${ }^{7}$; a mayor rendimiento, mayor éxito. Generalmente, en una economía liberal, el principal dinamismo consiste en que todos traten de comprar lo más barato posible y de vender lo más caro posible. De este modo: conocimiento, riqueza y éxito convertuntur. Como que la profecía contenida en el hay que aprender a administrar la riqueza (López Portillo), se cumple ahora en la administración del conocimiento: knowledge management de la era del conocimiento.

En este contexto, también llamado enfoque industrial de la educación, es el principio de la eficacia el que dicta cómo

\footnotetext{
${ }^{7}$ Esto ha permitido, por ejemplo, el nacimiento de la "Universidad de la Empresa", bastante popular entre los políticos y directivos del Reino Unido y Holanda y, desde ahí, en el mundo entero. Su éxito consiste, precisamente, en la producción de conocimientos comercializables.
} 
tienen que desarrollarse los sistemas educativos ordenados a garantizar los avances técnicos ${ }^{8}$. El éxito en cuanto a la formación de alumnos consiste en obtener del mejor modo, los mejores resultados prácticos, lo más pronto posible. Para evitar las tensiones entre los intereses individuales (desarrollo personal autodirigido) y las exigencias de una educación de personas económicamente activas (productores-consumidores-contribuyentes), se ofrecen las mejores oportunidades para que el alumnado adquiera las "competencias" -inmediatez, factibilidad, relevancia y utilidad- que le permitan ser considerado un buen trabajador hecho a la medida, favorezcan su éxito profesional y aseguren su felicidad terrena y -¿por qué no?- también la eterna (I wanna live forever, ¿no lo expresa así la letra de Fame?).

Se trata, en suma, del dominio de la técnica, con su desarrollo unidireccional del área de los medios y su abandono del área de los fines. Es la industria del conocimiento técnico ${ }^{9}$ que, por la celeridad de sus procesos, no puede reconocer lo que ha recibido del pasado; impotencia que le impide aprender algo de él y le tienta a autoerigirse en artífice único del progreso. Esto es lo que irónicamente se ha llamado la barbarie de la

${ }^{8}$ No hace falta aquí insistir en el valor e importancia del saber técnico. Bien sabemos que el bomo faber hace la técnica, como hace la filosofía, las ciencias, las artes, la cultura toda. Piensa, inventa, investiga y ejecuta actos encaminados a vencer cuantas dificultades se le presentan en el desarrollo del principio perfectivo que le es inherente y que fundamenta la ley del progreso impresa en su naturaleza. Con la técnica, el hombre escudriña, descubre, domina; crea, entre la naturaleza y su ser, algo que le separa, le eleva y le dignifica: le separa de los seres irracionales, le acerca a colocar la realidad del cosmos a su servicio y realiza las potencialidades ínsitas en su dignidad; trasciende la mera necesidad para instalarse en los terrenos de la libertad. Pero, si la ciencia y la técnica se constriñen a la aplicación utilitaria, comercial o política, y se las empuja a una síntesis forzada por las exigencias de la rapidez de los procesos productivo o demagógicos, terminan por hacerse formularias y dogmáticas, se debilitan y su debilidad puede provocar la debilidad de la producción y ésta, a su vez, de la economía.

${ }^{9}$ Como resultado de la comercialización del conocimiento, su producción se ha incrementado firmemente. Aunque cada diez años se duplica la cantidad total de conocimientos, el nuevo conocimiento tiende a hacerse obsoleto muy rápidamente, en particular en áreas tales como la tecnología de la información. 
tecnocracia, como el lado sombrío de la técnica que funciona, se mantiene y avanza gracias al vacío ético que provoca.

\section{LA INDUSTRIA DE LA «EDUCACIÓN"}

El binomio paradigma del éxito-tecnocracia ha propiciado el llamado modelo de competencia minima (Biddle, Good y Goodson: 85), según el cual la educación es un sistema de distribución arbitrario, impuesto, diseñado y estructurado mercantil y burocráticamente, como resultado del debate político-económico, más que del diálogo entre la pedagogía y las partes interesadas.

Este modelo, también llamado enfoque directivo-burocrático de la educación (Idem.), ha desencadenado un nuevo debate acerca del papel del profesor y su formación. En este contexto, el profesor es un técnico capaz de implementar el currículum que ha sido definido y diseñado por grupos externos (política, empresa).

Ya no hay profesores sino trabajadores de la enseñanza que han perdido su posición central en la educación; simplemente cumplen con su parte en el proceso de producción llamado "instrucción" (Ibid. 86).

Conocimiento de la materia y competencia instruccional, bastan para impartir con éxito el currículum. Esto permite grandes ahorros en cuanto a la formación del profesor, ya que transforma el proceso de "educar" profesores, en un proceso de "capacitar" profesores; y hace más fácil evaluarlos, juzgando en qué medida cumplen su cometido técnico-docente, en el entendido de que todo el modelo está organizado de tal modo que las deficiencias puedan remediarse fácilmente. Así, las escuelas de formación del profesorado pasan a ser centros de capacitación de habilidades docentes, olvidando la necesidad de adquirir calidades ético-pedagógicas. No se les prepara para conducir con autonomía su propia preparación; ni se les facilita la realización de experiencias variadas que les pongan en situación de abrir sus horizontes, 
ampliar su cultura, perfeccionar constantemente su actividad y acceder libremente a mejores condiciones laborales.

Esto tiene su importancia con relación a nuestro tema central, si se considera que, en el mundo maravilloso del éxito, la industria de la educación agudiza viejos conflictos en el profesorado, encargado de formar personas aptas para construir, participar, triunfar y gozar de ese mundo feliz: el mundo del éxito social (status, poder, riqueza), del que el profesor, ordinariamente, queda excluido de antemano. Algo de trasfondo hay cuando se dice, entre veras y bromas, que: ¿Cómo puede evaluar actitudes un profesor, si cada semestre tiene 10 ó más cursos y 400 ó 500 alumnos? O que: El profesor que intente formular sus exámenes de acuerdo con los objetivos de Bloom, muere de agotamiento o de hambre. O bien que: El profesor que tenga todos los conocimientos, habilidades, actitudes, competencias y virtudes que exige todo perfil didáctico, no estaría trabajando de profesor.

\section{EL «PARADIGMA DEL ÉXITO»}

La efervescencia por el paradigma del éxito comenzó, principalmente, en ambientes extra-pedagógicos (política, empresa, finanzas, deportes, medios de comunicación y eso que se ha dado en llamar el gran mundo). Pero dadas las relaciones sistémicas entre todas las áreas del quehacer humano, el trabajo pedagógico muy pronto se vio involucrado en este movimiento de carácter casi universal. Paulatinamente la educación quedó reducida a enseñanza eficaz de un conjunto de materias, en la que se margina la preocupación por los problemas fundamentales del hombre, porque se considera que las humanidades son incapaces de responder a las necesidades de nuestra época técnica e industrial. Con lo cual el hombre mismo se cierra el acceso a lo propiamente humano.

Es verdad que las Humanidades están más relacionadas con los fines de la empresa humana que con los medios. No desprecian los medios, pero dan prioridad a los fines. La 
técnica, como tal, no habla de los fines del hombre. Por lo mismo, corre el riesgo de volverse indiferente a los valores humanos; está maravillosamente dispuesta a decirnos cómo conseguir un determinado fin, pero, primero, ese fin debe darse. El triste dilema del científico de hoy es considerar que su ciencia puede igualmente dirigirse al bien o al mal. Su orientación debe venir de otro sitio.

Al margen de esto, en muchos ambientes académicos se intentó el desarrollo de la llamada pedagogía del éxito, representada por la gran cantidad de películas, programas de televisión y artículos de las revistas norteamericanas:

(...) acerca de la historia prodigiosamente sencilla de los millones de sus más caracterizados magnates del dinero, que tienta a vivirla al lector ingenuo, y sobre el facilísimo arte de hacerse millonario, que se cifra en desearlo de veras e hinchar el pecho diciéndose con mucha convicción: creo en mí, yo puedo, tengo confianza en mí, nacido para triunfar, isoy un gigante!, iyo: el emprendedor!... (Hernández Ruiz: 24).

Tal actitud nos recuerda el paralogismo emblemático de la modernidad: Quiero ser un triunfador, pienso que soy un triunfador; luego: soy un triunfador. (Y nos recuerda también la simpática chifladura de "El Rey" de la popular canción, que en un arranque de "autoestima" sentencia: Con dinero y sin dinero,/ hago siempre lo que quiero, /y mi palabra es la ley! Menos mal que, al parecer, se trata de una chifladura inofensiva en cuanto que reconoce: No tengo trono, ni reina,/ ni nadie que me comprenda,/ ipero sigo siendo el rey!). Desde luego que una actitud anhelante y una filosofía entusiasta importan mucho cuando de lograr el éxito se trata, pero no son suficientes para convertir -decía Píndaro- bellos sueños en palpables realidades. Según Mencio: El hombre debe decidir qué es lo que no va a hacer; entonces podrá dedicarse con vigor a lo que debe hacer.

Como quiera que sea, para unos, el éxito es como una obsesión, una idolatría, su fin último natural y, por lo visto, 
también sobrenatural. Otros lo ven como una tentación frívola, propia de gente ambiciosa y pícara: es la tensión dialéctica entre nosotros los pobres (ergo: honrados, buenos y felices) y ustedes los ricos (ergo: inmorales, perversos y desgraciados). Mientras tanto, el éxito -la figura del triunfador, la imagen del ganador-, parece haberse convertido en el modelo paradigmático de cierta pedagogía, porque es la reproducción de ese paradigma lo que la sociedad tecnocratizada, la industria de la educación y la politica economizada -o economía politizada-, reclaman.

Es notorio y por ello preocupante, que en las universidades, como lo ha señalado Derek Bok, ex presidente de la Universidad de Harvard, se hable cada vez más con un lenguaje propio de los negocios y no con el de la ciencia y el conocimiento. Las universidades, ante el prestigio y el liderazgo del sector empresarial, están imitando sus formas de organización, su lenguaje y quién sabe si hasta sus objetivos y metas. (...) Hoy es común oír hablar a directivos y profesores universitarios de "la penetración en el mercado", de "la fuerza o el valor de la marca", de "los productos con los que se puede competir" -para referirse a los programas o cursos que imparten-, de "los clientes" -los alumnos y estudiantes- y del "margen o rentabilidad con el que operan (Felipe González, Istmo, 270).

\section{FENOMENOLOGÍA DEL ÉXITO}

Cuando preguntamos por ahí: ¿qué es el éxito?; ¿en qué consiste ser un triunfador? las respuestas suelen ser muy diversas y contrastantes ${ }^{10}$. Esto no es extraño. La respuesta

\footnotetext{
${ }^{10}$ Éxito es un concepto polisémico; incluye un abanico demasiado grande y flexible de significados. Para algunos, el éxito es un privilegio reservado para muy pocos: aquellos que han llegado -se dice-. Riqueza, poder, placer serían las notas características de ese "éxito". Para otros, tener éxito significa lograr sobrevivir en medio de la marginación y la miseria. Entre esos extremos se encuentran aquéllos para quienes "hacerse de un auto", un televisor o una "casita", son muestra de un status exitoso; desde montar un negocio, hasta ser "hombre de negocios". No falta quien piense que "Salir en la televisión o en la prensa" es sinónimo de fama y de éxito. Otros, muchos, suponen que incursionar en los terrenos de la política, es garantía segura de éxito. Ya los griegos hablaban del "éxito" del osteoteeteta: «buscador de hueso", "perro", para referirse al funcionario público venal, que convertía su empleo en una sinecura, o se valía de él para traficar con influencias y medrar por medios corruptos. (Estoy hablando de la Grecia antigua, que conste).
} 
exige cierta experiencia y criterio muy personales. Además, en los arquetipos exitosos con los que tenemos contacto concurren intereses elitistas, maniqueístas, comerciales e ideológicos. Por otra parte, estamos en una época de gran confusión semántica que convierte las palabras en clichés, en slogans, y deviene en subversión axiológica. Por ello, antes de analizar la legitimidad del paradigma del éxito, conviene echar una mirada al éxito tal como suele aparecer, si no en nosotros, al menos ante nosotros. Analizar los fenómenos que ocurren en la esfera de los asuntos humanos ta tôn anthrôpôn pragmata, como la llama Hanna Arendt- y que normalmente se asocian con lo que se conoce como éxito, y de ese análisis, tratar de dilucidar su naturaleza.

Aun así, reconozco que querer formular una fenomenología del éxito, da la impresión de que se está intentando una temeridad. Éxito es, como otros conceptos análogos (en parte iguales y en parte distintos: felicidad, triunfo, bienestar, realización, etcétera), sumamente complejo, protéico, fácilmente confundible. Querer describir el éxito es como querer armar un puzzle del que siempre faltan o sobran piezas, dejando sólo un cierto olor a fracaso.

Produce, también, la sensación de estar aludiendo a una trivialidad. El éxito es una realidad tan prosaica... toda persona quiere alcanzar el éxito; a nadie le gusta fracasar en aquello que intenta. Además, quien más quien menos tiene en su haber pequeños, medianos o grandes éxitos en lo personal, familiar, académico, profesional, social..., aunque no sean anunciados en los medios (desde la estrellita en la frente del niño de kinder, leer un libro completo, hasta lograr terminar de escribir un artículo). Y por si fuera poco, produce también la sensación de inoportunidad. ¡Se habla tanto del éxito! Se le define, describe, ofrece y vende, con una frecuencia y facilidad sorprendentes.

A pesar de ello, o precisamente por ello, una fenomenología del éxito deberá poner de relieve las notas que han de tomarse 
en cuenta, si no para definirlo, al menos para caracterizarlo. Oteando la cultura que nos rodea, podemos señalar, del éxito:

a) Su universalidad... al menos como deseo. Así como todos los hombres quieren ser felices, igualmente quieren ser triunfadores, exitosos, "ganadores". En esto no parece haber excepción. Aun sin tener conciencia de ello, todo mundo quiere lograr el éxito de las acciones que emprende: el niño que intenta dar sus primeros pasos, o leer y escribir; quien limpia coches en un crucero; la madre empeñada en que su hijo tome el desayuno; aquel que anhela acceder a un cargo de mayor prestigio y remuneración; el otro que aspira a ser galardonado con el Premio Nobel. Y también, en su acción, busca el éxito el que miente, el que roba, el traficante, el suicida... Porque:

Toda acción tiene algo que ver con el logro del objeto del deseo, que es la meta de la acción. La misma fuerza que ha separado a los hombres, que ha enfrentado a unas naciones con otras, que ha raído pueblos, razas e individuos de la faz de la tierra es aquélla en la que todos coinciden, porque todos quieren lo que quieren, todos desean algo... y porque lo desean, actúan (Farell: 21).

Hay, por lo tanto, deseos de signo positivo o negativo que buscan el resultado exitoso. Sin embargo, el sentir común advierte que, por su misma índole, la acción exitosa debe ser efecto positivo de deseos positivos, acordes a la dignidad humana: deseos dignos. Y sólo son dignos los deseos que dan lugar a acciones dignas: ¡dime qué deseas y te diré cómo eres! Parafraseando a Kant podemos decir que es propio y original del hombre buscar el éxito, sólo que debe también buscar ser digno del éxito.

El hombre se mueve por fines; goza de la maravillosa facultad de proyectarse fuera de sí mismo, de contemplarse como espectador de su vida, pudiendo apreciar así su significado. Mirando hacia delante, es capaz de comprender que la meta a la que aspira no sólo da un cierto aroma a lo que hace, 
sino que lo explica, ya que de la naturaleza de esa meta depende el significado de su vida, de su actividad y de su propio destino. Buscar el éxito es preguntarse: ¿qué es "tener éxito"?, ¿por qué lo deseo; para qué lo quiero?, ¿qué clase de persona quiero ser?, ¿a dónde quiero llegar? No saber esto constituye la terrible arbitrariedad con la que se enfrentan algunos cuando deciden embarcarse en este tipo de acciones (Arendt, 71). El dicho popular también es muy claro a este respecto: Si no sabes a dónde vas, no importa el camino que tomes.

b) Su practicidad. Desear, ordinariamente, conduce a proyectar: proyecto personal, familiar, académico, profesional, de vida... Pero proyectar no es realizar, hace falta pasar de la teoría a la práctica. Del éxito podemos afirmar lo que Aristóteles dijo de la felicidad: el éxito, el auténtico, no se debe a un golpe de suerte, a una sonrisa de Tiké (mítica diosa de la Fortuna). $\mathrm{Ni}$ es obra de un diablillo bueno (eu, daimon), a modo de ángel, carisma, simpatía, belleza, encanto... Es, más bien, el fruto de ideas ingeniosas, fecundadas por el trabajo, el esfuerzo, el orden, la precisión y la constancia. Es decir: de todo lo que Víctor Hugo pone en su Jean Valjean. La búsqueda del éxito es práctica, operativa; estimula el dinamismo natural del hombre; genera, sostiene y encauza el interés; conmina a no conformarse con lo que se halla casi sin esfuerzo y a no pactar con la mediocridad. El entusiasmo -sentencia Henry Ford- es tu irresistible fuerza de voluntad y la energía para realizar tus ideas. Es la base de todo progreso. El porvenir de un hombre -según William Shakespeare- no está en las estrellas, sino en la voluntad y en el dominio de sí mismo.

Queda claro, pues, que el éxito es consecuencia práctica del deseo eficaz. Porque desear es buscar, con afán, algo que no se tiene. La ausencia total de afán, es señal de que no hay deseo (sería un "quiero" que no pasa de ser un "cómo me gustaría). El deseo, para ser eficaz, debe dar lugar a la acción. Actuar, en su sentido más general, significa tomar una iniciativa, comenzar, como indica la palabra griega arkhein, o poner algo 
en movimiento, que es el significado original del agere latino (Arendt: 103). Actividad significa, entonces, poner en acto: actualizar lo potencial, realizar (convertir en realidad) lo meramente posible.

La actividad propiamente humana es compleja, inteligente y libre. Puede ser teórica, práctica y/o productiva. En ella se entretejen deseos y acciones dignas o indignas, nimias o relevantes, exitosas o malogradas. Pero hay un elemento que da sentido y cohesión al continuum de lo que el hombre hace: ese elemento de armonía y unidad, es el deseo humano. La intensidad del deseo se mide por la intensidad de la puesta en práctica de la búsqueda.

Todo mundo desea el éxito; luego hay que decidir qué hacer, qué camino seguir para satisfacer tal deseo; poner por obra lo decidido $\mathrm{y}$, finalmente, disfrutar o padecer los resultados del proceso.

c) Su efectividad. Dicen, los que de esto entienden, que lo que comunica razón de ser y efectividad a la lucha por lograr el triunfo es, sobre todo, la claridad de los objetivos, la intensidad del esfuerzo y la fortaleza con que se acomete y se resiste. No bastan los buenos deseos: hay que llegar al final. A este respecto, debe reaccionarse continuamente contra la inconstancia, la indolencia, las decisiones injustificadas, la falta de resolución, para que pueda desarrollarse y cultivarse el talento (Kriekemans: 23). Ésta es la causa de que el éxito haya de ser evaluado no sólo por su fin (cualidad de los resultados), sino también por su principio (eficacia del deseo), por la elección de los medios (acierto en la decisión y en la elección) y por la efectividad de las acciones mediante las cuales se hizo posible su realización. Traído a nuestro terreno, esto querría decir que el propósito de la educación debe ser, primordialmente, que el educando aprenda, más que a tener éxito, a elegir y realizar de la mejor manera sus acciones. El logro del éxito, más que ser el objetivo, es el resultado del bien desear, del bien elegir y del bien actuar ${ }^{11}$. Esto es lo que 
Kriekemans llama: despertar las mejores disposiciones de la voluntad, que ubica a la persona en el terreno de las grandes decisiones, y la compromete a vivir su vida y a edificarla bajo su propia responsabilidad.

Las disposiciones de la voluntad son esencialmente teleológicas. Todo acto voluntario se orienta a la consecución de aquello que se le presenta como un bien y que asume la condición de fin.

El objetivo significa la precisión del término o del resultado probable de nuestra acción. Actuar con un objetivo previsto es actuar inteligentemente; redunda siempre en actividades dispuestas y ordenadas para alcanzarlo. El objetivo es, pues, el principio que gobierna y dirige toda nuestra actividad e influye en cada uno de los pasos que damos para llegar a él (John Dewey).

El sentido de la vida nos lo dictan nuestros ideales (propósitos), la tarea de realizarlos y los resultados obtenidos. Técnicamente se explica que la verdadera causa de una cosa es lo que para esa cosa es lo mejor. Esto significa que la actividad humana bien orientada y bien realizada, es la causa o principio del éxito. Si el principio causal produce los resultados previstos, el efecto es perfecto -el éxito se da-; de no ser así, el efecto es defecto -el efecto no se da-.

No obtener los resultados previstos significa inefectibidad: fracaso. Obtenerlos de manera incompleta, denota cierto efecto abortivo, inmadurez del fruto: mediocridad, quizá no en la pretensión, pero sí en el logro. En ambos casos es frustración. Ésta, sea grande o muchas pequeñas acumuladas o prolongadas en el tiempo, conducen a sentimientos de minusvalía, apocamiento o autodesprecio (baja autoestima, se dice); o actitudes de hostilidad, rebeldía y agresividad. La ma-

\footnotetext{
${ }^{11}$ Esto, a mi modo de ver, lo entendieron muy bien nuestros antiguos náhoas cuando aconsejaban al educador: temachtiani (formador de rostros, de personalidades, de caracteres), con respecto al educando: "Enséñale a humanizar su querer"; es decir: que su querer sea cada vez más inteligente y libre.
} 
durez humana, en gran parte, depende de la capacidad de asimilar los propios éxitos y fracasos. Bien manejado, el fracaso aceptado, comprendido y superado, es fuente de nuevas, más enérgicas, optimistas y efectivas motivaciones.

Cerrar los ojos a la posibilidad de fracasar, conformarse con la "mentalidad de triunfador", conduce a lo que podríamos llamar: "síndrome bovarista", derivado de Madame Bovary, la famosa obra de Flaubert, para indicar la actitud del que se crea a sí mismo una personalidad ficticia e intenta vivir conforme a ella. A la pregunta: ¿Quién es Madame Bovary?, se atribuye a Flaubert la respuesta: Emma Bovary c'est moi . Es el éxito del que es winner porque él así se siente; tiene mentalidad de triunfador porque él así se percibe, sin realizaciones efectivas que la respalden ${ }^{12}$.

d) Su positividad. Ya lo dijimos: puede tratarse, por ejemplo, de conquistar una cumbre, sacar adelante una familia, construir un edificio, ganar una competencia, ver claro en una cuestión difícil, superar un defecto del carácter... O bien: consumar un robo, llevar a cabo un atentado, enriquecerse mediante la explotación del trabajador, hacer la guerra injustamente, malversar fondos del erario público, valerse de la ignorancia de alguien para causarle un perjuicio... Hay, pues, acciones buenas y acciones malas. Hasta el "proyecto ético" más light, con su moral precarizada que permea la cultura actual, admite, casi como argumento fáctico, que los actos humanos -en este

\footnotetext{
12 "Es -señala A. Caso- la construcción de un ángulo que, teniendo por vértice el propio individuo, tiene por lados las dos direcciones diversas, la propia y la ficticia... Basta que una idea asome a la conciencia, para que creamos que es realidad; imaginamos algo y propendemos a su realización en la fantasía. Nos creamos un "yo" ficticio, forjado en nuestros sueños. Un "yo" que ve al mundo como queremos que sea, no como es; y nos vamos sacrificando a nuestra propia mentira, a nuestro ideal, a nuestro sueño... Así, nos creemos pensadores y no lo somos; poetas, tal vez, y no somos poetas, mártires sublimes o santos redentores, y sólo en el delirio de nuestra fantasía redimimos y nos sacrificamos... De aquí la tragedia del bovarismo ( Apud: Lerma Jasso, Héctor., La subjetividad en Jean-Jacques Rousseau., EUNSA., Pamplona., 2003., p.74).
} 
caso los actos humanos que aspiran al éxito- pueden ser, desde el punto de vista moral, de estimación positiva o negativa. Insistir en esta distinción es importante porque, así como hay acciones pequeñas o grandes, duraderas o efímeras, las hay buenas o malas según su rectitud moral. De cómo entendamos esta distinción y cómo la apliquemos, dependerá nuestro modus vivendi, nuestro modus operandi y nuestro modus con-vivendi (Moratalla: 62).

Mahatma Gandhi, apóstol nacional y religioso, es claro ejemplo de una lucha decisiva, sacrificada y no violenta por defender a su pueblo contra la discriminación y la explotación. La galardonada con el Premio Nobel de la Paz, Teresa de Calcuta, representa el coraje y la firmeza de carácter, la abnegación y solicitud al realizar, con caridad cristiana, su trabajo a favor de los pobres y enfermos. En cambio, Macbeth y Lady Macbeth, según la versión de Shakespeare, personifican la codicia de poder y riqueza, conseguidos por medio de la intriga, la impostura y el crimen; perversión que casi encuentra su justificación racional y hasta científica en el maquiavelismo atribuido a célebre pensador florentino, propugnador de un pragmatismo amoral indispensable para el éxito politico.

Estas oscilaciones de la conducta humana, son posibles porque, aunque el hombre siempre elige un bien, no siempre elige bien. Por eso, los actos humanos (en los que intervienen la inteligencia y la voluntad libre) pueden ser reputados moralmente como buenos o malos. Se entiende, por lo tanto, que el éxito deba medirse por la bondad de la elección, la bondad de la acción y la bondad de los resultados. El triunfo, más que una conquista técnica, es un mérito ético. De otra forma, más que triunfo, es una traición a la cultura y una traición a la libertad. El bien no se desarrolla en el mal, y el mal no se desarrolla en el bien (Arendt, 160). En la práctica, ética y técnica son realidades separables. De hecho:

- se pueden obtener buenos resultados de acciones moralmente lícitas; o 
- buenos resultados de acciones moralmente reprobables; o

- los mejores resultados de buenas acciones técnicamente bien hechas; o

- los mejores resultados de acciones éticamente ilícitas, pero técnicamente bien hechas; $\mathrm{O}$

- los mejores resultados de las mejores acciones, éticamente y técnicamente, mejor realizadas.

El resultado máximamente exitoso estribaría en la última alternativa. O, como lo dice Carlos Cardona: se trata de hacer el bien, bien; el bien, bien becho, queriendo bacerlo precisamente porque es el bien. Y, con palabras de Séneca, podemos añadir que el hecho de haber-hecho bien el bien, es el mayor éxito para lo becho y para su hacedor. No todo lo que resulta exitoso desde el punto de vista técnico, lo es desde el punto de vista ético. Técnica y ética son -repitonociones separables, en la práctica, pero cuando esto ocurre, surgen las injusticias que padecemos: corruptos, charlatanes, estafadores, criminales, embaucadores... "exitosos"; y personas capaces, honradas, trabajadoras... sin relieve ni reconocimiento. Stuart-Mill lo diría más ásperamente: Más vale un Sócrates modesto, que un imbécil encumbrado.

No sólo tenemos necesidad de técnica, sino también de verdad, justicia, belleza; de los ideales, sin los cuales la sociedad no puede genuinamente progresar. La educación está obligada a desarrollar una labor de saneamiento material, cultural, moral. Antes que nada, tiene que sanearse a sí misma. No admirar al estafador, al hombre sin escrúpulos, al pícaro que se enriquece a base de medrar, al truhán que se eleva a base de pesar poco... Es preciso distinguir, y enseñar a distinguir, el éxito del mérito, e impedir que triunfe quien no lo merezca (Elía: 422).

e) Su consistencia. Lo ganado, con el éxito, debe ser, comparativamente hablando, mayor y mejor que lo invertido. Se trata de no sacrificar lo más por lo menos. Si en un negocio 
invierto equis cantidad de dinero, el rendimiento, para ser considerado exitoso, deberá ser notablemente superior a esa cantidad. Si no es así, el éxito es sólo aparente, inconsistente, puede ser una modalidad del fracaso.

Deborah Legorreta, psicóloga, con una experiencia de más de diez años como asesora de empresa, nos ofrece un ejemplo de esta asimetría cuando explica que:

Se ha podido comprobar, en sesiones de psicoterapia, que algunas mujeres mayores de cuarenta años, inteligentes, trabajadoras y reconocidas profesionalmente, llegan a la triste conclusión de que han sacrificado algún aspecto crucial de su identidad, sus valores o su salud, en la danza desenfrenada de la ocupación adictiva, y han perdido el control de su propia vida ${ }^{13}$.

La historia y el arte nos muestran ejemplos ya clásicos a este respecto. Uno de ellos es el que podríamos llamar: "síndrome de Fausto" ${ }^{14}$, que consiste en ganar bienes inferiores, a base de sacrificar bienes superiores. Un caso similar es la llamada "victoria pírrica" ${ }^{15}$, en el sentido de obtener un éxito muy valioso -apantallante-, a costa de esfuerzos y penalidades que no justifican lo obtenido.

Y, ateniéndonos a la "cultura" que nos llega a través de los medios, es evidente que existen, también, "éxitos" repentinos,

\footnotetext{
${ }^{13}$ Legorreta, Débora., "Las tres "es" del éxito femenino: Eficacia, Ética y Equilibrio de vida", en Revista Paula., mayo 2002., No. 97., México, pp.80-84.

${ }^{14}$ Esto en alusión a Fausto, el conocido héroe de numerosas obras literarias que, a su vez, ha inspirado a músicos, pintores, cineastas... Según la narración, Fausto, ya adulto en plenitud-como se dice ahora-, hombre sabio, bueno y piadoso, sucumbe a la tentación que le presenta Mefistófeles (el diablo): le vende su alma a cambio de juventud, amores, riqueza y demás bienes terrenales. El personaje de Fausto -dicho sea de paso-, según diversos autores, parece haberse convertido en el arquetipo del llamado bombre moderno u hombre fáustico: confió a la ciencia tecnificada y al progreso material su suerte y su destino, y mucho ganó, pero mucho perdió.

${ }^{15}$ Pirro, rey del Epiro, aguerrido rival de Roma. Luchó contra los romanos con ardor en varias batallas memorables. No obstante, pagó tan cara su victoria (perdió la mayor parte de sus mejores soldados, mandos y amigos; las arcas de su reino quedaron depauperadas; su pueblo quedó en la miseria...) que terminó por exclamar: «¡otra victoria como ésta y estoy perdido!».
} 
pasajeros y, por ello, inconsistentes: una canción, un libro, una película, una victoria atlética, una gestión pública...: cuya lozanía es como flor de heno. Secóse el heno y cayó la flor... ${ }^{16}$. Son "triunfos" tan efímeros que, al esfumarse, sólo dejan una profunda sensación de fracaso y... una fuerte adicción. Por eso hay divas y divos que, en cuanto los bajan del pedestal, insisten en despedirse diez, cien, mil veces. Es cuando el "éxito", por su inconsistencia, puede convertirse en ridículo. Con razón se dice que más altas están las nubes y el aire las desvanece.

Otros "triunfadores", quizá atenidos a que el trabajo no te hace rico, sino jorobado, buscan triunfar mediante el fácil -y trágico- recurso de empeñar la dignidad, el honor, la conciencia... Hay "éxitos" -ya lo dijimos- que se obtienen a base de escándalos o fraudes; de traicionar las normas de la verdad y de la justicia: de engañar, adular, contemporizar, ceder... confirmando aquello de que: quien cede en poco, cede poco a poco; es, justamente, el camino de la sedimentación moral. Luego, a quienes detentan esos "éxitos", no les queda más que elaborar ingeniosísimas teorías para justificar lo que, en buen crisol, no tiene justificación; para convencerse de que ellos están bien y todos los demás están mal. ¿o ha habido siempre sistemas «educativos" encargados de formar "dialécticos", en el sentido erístico del término: el arte de defender hasta lo indefendible?

Recordemos, también, que hay "éxitos" que se obtienen torpemente, como en el llamado "síndrome de Midas" "17, quien gozó muy poco de su "éxito", apenas lo suficiente para poner su vida y la de su familia en grave riesgo. Y también hay

\footnotetext{
${ }^{16}$ I Pe, 24.

${ }^{17}$ ¿Se acuerda usted del mítico rey Midas? Se asegura que no fue malo, sólo fue estúpido. Suplicó a Baco que le concediera el poder de que todo cuanto tocara se convirtiera en oro. Su deseo le fue concedido pero pronto se percató de su error cuando, en la primera comida, al llevarse los alimentos a la boca únicamente mordió el metal. Otro tanto ocurrió cuando quiso beber agua, pero más grave fue su dramática situación cuando intentó acariciar a su amada hija, a la que ipso facto convirtió en una estatua de metal. Consternado, desesperado, hambriento y sediento, se vio obligado a pedir al dios que le retira aquel favor.
} 
- ¿cómo no?- una especie de "peterpanismo" de quien no quiere crecer, que en una especie de marasmo, se niega a todo logro, a todo avance, a todo "éxito", quizá por miedo al esfuerzo o al compromiso. Constituyen, obviamente, retos interesantes para una buena labor de ortopedagogía.

f) Su jerarquización. Tender al éxito es, en definitiva, tender a que la voluntad se satisfaga. Solamente una voluntad libre es capaz de éxito. La voluntad (apetito intelectual o racional, cuyo acto es querer) es tan abierta como el pensamiento: puede querer cualquier cosa, hasta lo imposible ${ }^{18}$. Querer el éxito es querer un bien; querer los bienes que el éxito trae consigo, es querer un conjunto de bienes, todos valiosos y jerarquizables.

Los bienes sensibles o materiales, sin duda, son muy importantes y valiosos: pueden ayudar a reparar las fuerzas deprimidas, animan, consuelan, alegran; comunican cierta seguridad. Crean un cierto "bien estar" que puede y debe ordenarse al "bien ser", de otro modo se vuelven excluyentes en su disfrute. Además, su consustancial incapacidad para aplacar la sed del hombre, suele causar insatisfacción ante lo que se posee, ansiedad ilimitada y creciente, y un estado permanente de competencia con quienes tienen o parecen tener más. En nuestros días, se hace más acuciante la posible mitificación del bienestar material que causa en las personalidades débiles, el efecto de una droga paralizadora que, con las posibilidades crecientes de influencia, ocio y diversión, consumen toda probabilidad de elevación, para correr sin freno a la caza de las satisfacciones inmediatas externas, clamorosas, del week-end más dispersivo y depresivo (Ibáñez-Martín: 116).

\footnotetext{
${ }^{18}$ No es posible -ni necesario- exponer la doctrina del acto voluntario. Baste recordar que todo aquello hacia lo cual el hombre tiene una inclinación natural, es naturalmente captado por la razón como algo bueno y, por lo tanto, digno de ser conseguido; lo contrario es captado como algo malo, negativo o vicioso, que hay que rechazar (Cfr. Yepes, 41). Por eso se dice que el bien es lo que todos apetecen; porque es la perfección correspondiente a una naturaleza. Esta bondad se extiende a todo lo que es, a todo lo que existe. Es decir, la raíz del bien está en el ser. El bien es una conveniencia y un valor moral.
} 
Los bienes sensibles son medio, no fin. Se ordenan a los bienes espirituales: al saber y a la virtud que, a su vez, conducen al reconocimiento y estimación que más adelante estudiaremos como fama y honor. Esto es: saberse y sentirse digno y respetable ante sí y ante los demás. Todos los bienes materiales y espirituales deben apuntar a eso que se entiende como plenitud de vida.

No es, pues, prudente ni justo, impugnar los bienes materiales ni el tener material. Cuando se afirma que el hombre es esencialmente "habitante" (de babere = tener), se está aludiendo a los diversos modos de tener: tener técnico (material o físico: tener con el cuerpo; lo asido, puesto, ahorrado, invertido...); tener teórico (es el tener cognoscitivo: lo conocido, sabido, creído: ciencia, fe, convicciones, valores...); tener moral (tener como experiencia, tendencia, hábitos, virtudes, cualidades...). De ahí que:

Nada más legítimo para la vida del hombre, en su itinerario terreno, que la aspiración al bienestar. Los bienes materiales, en medida suficiente, producen confort; incluso con algún despliegue inocente a las regiones de lo superfluo, es condición indispensable para el ejercicio válido y productivo de las facultades de trabajo en todos los campos, aun el del espíritu (Ibáñez-Martín: 117).

Ya Aristóteles consideraba que la vida buena (distinta de la buena vida) contiene y posee los bienes más preciados. Sin pretender que esta relación resulte actualmente exhaustiva, él señala: la familia y los hijos en el hogar, una moderada cantidad de riquezas, los buenos amigos, una moderada buena suerte o fortuna que aleje de nosotros la desgracia; fama, honor, buena salud y, sobre todo, una vida nutrida en la contemplación de la verdad y la práctica de la virtud. Más próximo a nosotros en el tiempo, David J. Schwartz enumera:

¿Qué se entiende por éxito? "Éxito significa muchas cosas maravillosas, positivas. Éxito significa prosperidad personal: un hogar atrayente, vacaciones, viajes, cosas nuevas, seguridad financiera, 
dar a los hijos las máximas ventajas. También significa admiración, liderato, ser visto con respeto por la gente en su vida social y de negocios. Significa libertad; liberarse de preocupaciones, temores, frustraciones y fracasos. Significa auto-respeto, encontrar continuamente más satisfacción y felicidad en la vida, la posibilidad de hacer más por aquellos que dependen de usted. Éxito significa triunfo. ¡El éxito -realización- es la meta de la vida!» (Schwartz: 1991:19).

A este respecto: ¿recuerda usted el caso de Tales de Mileto?

Un sabio, de gran ingenio ${ }^{19}$, que vivía en extrema pobreza, causando extrañeza a sus contemporáneos. Cierto día, absorto en sus investigaciones y observando los astros del cielo, dio con sus buesos en un pozo. Una muchacha se burló de él: Tales, por estar tan ocupado contemplando las cosas del cielo, no te percatas de las cosas de la tierra. Él, queriendo demostrar la superioridad de los bienes del espíritu, aprovechando su ciencia, logró entrever que, mientras era aún invierno, iba a baber una gran cosecha de aceitunas. Reunió una pequeña suma de dinero y rentó, a bajo precio, gran cantidad de las bodegas y prensas de aceituna. Llegada la estación, la cosecha fue tan abundante, que hubo una demanda imprevista y repentina de bodegas y prensas simultáneamente. Tales aprovechó para alquilarlas al precio y condiciones que quiso. Gracias al éxito de este negocio, acumuló gran suma de dinero que, al parecer, repartió entre los pobres del lugar, demostrando así que, si él quisiera, le sería fácil volverse rico, pero que los bienes que a él le importaban eran de índole superior.

A mi modo de ver, se le pasó la mano a Tales (o a sus biógrafos: Platón y Aristóteles). Pero, cierta o no, la anécdota ilustra el hecho de que no todo éxito tiene por qué medirse por sus resultados materiales, aunque, normalmente, los bienes

19 Tales de Mileto, considerado el padre de la filosofía, desempeñó un papel político importante en su patria, fue astrónomo (predijo un eclipse solar), físico (descubrió las propiedades del imán) y matemático (estableció varios teoremas de geometría, principalmente el que lleva su nombre). 
constituyen un plexus sistémico; en él, unos refieren a otros. A esto se debe que la posesión de bienes útiles -instrumentales, técnicos, materiales, económicos...-, como medios de vida, trabajo y estudio, abran al sujeto mayores horizontes espirituales, familiares, profesionales, culturales, sociales, morales, lúdicos... y lo descarguen de preocupaciones que en otro caso no dejarían - con la opresión de la privación- de producir un influjo paralizador.

g) Su bipolaridad. Los resultados del éxito son bipolares: se dan fuera del sujeto (polo objetivo) y en el sujeto (polo subjetivo). Esto es así porque: El hombre es el único ser que no puede actuar sin mejorar o empeorar. Hanna Arendt explica así cierto pasaje de De Monarchia, de Dante:

Porque, en toda acción, lo que intenta principalmente el agente (...) es manifestar su propia imagen. De ahí que todo agente, en tanto que hace, se deleita en hacer; puesto que todo lo que es, apetece su ser, y puesto que en la acción el ser del agente está de algún modo ampliado, la delicia necesariamente sigue... Así, nadie actúa a menos que al actuar haga patente su latente yo. A pesar de ser desconocido por la persona, la acción es intensamente personal. La acción sin un nombre, un "quién" ligado a ella, carece de significado, mientras que una obra de arte retiene su relevancia conozcamos o no el nombre del artista. Permítanme recordarles los monumentos al Soldado Desconocido tras la Primera Guerra Mundial. Son el testimonio de la necesidad de encontrar un "quién", un alguien identificable, al que hubieran revelado los cuatro años de matanzas (Arendt, 104).

No se puede, entonces, considerar el éxito, o la acción exitosa en cuanto acto humano, sin considerar en qué estado queda el hombre que lo realiza y disfruta. Si el éxito, en cualquier campo, no hace al "triunfador" mejor persona (no sólo más poderoso, rico, famoso, envidiado...), sino mejor persona, ese éxito, en su parte sustancial, se frustra, se malogra. Sería, hipócritamente, pretender que parecer bueno es más importante que el ser bueno. Las virtudes se reducen a meras 
condiciones para el éxito social de la acción exterior; impostura que se da por el traslado mecánico de las mismas, cuyo fondo tiene mucho que ver con el puritanismo convencional para el que, en vías del éxito, es menos importante ser bueno que actuar pareciéndolo (Llano: 67).

A esto se debe que esté demasiado difundida la creencia de que ciertos valores (entrega, ética, calidez, esmero, diálogo, lealtad...), son sólo estrategias para ser un buen trabajador o ejecutivo competente, sin reconocer que son cualidades para ser mejores personas. No es sensato, por ejemplo, ser fiel al cliente e infiel al cónyuge, obsequioso con los jefes y déspota con los hijos, ayuda positiva para la empresa y una desgraciada carga para la familia... Es cuando el éxito profesional conduce al fracaso personal y familiar.

Una buena educación debe hacernos entender que el hombre exitoso debe hacerse hombre bueno; y que el hombre bueno, que hace el bien, se está haciendo más bueno cuando hace el bien: va adquiriendo hábitos, capacidades, virtualidades, se está convirtiendo en un hombre íntegro, en una auténtica "buena persona" (en el buen sentido de la palabra, diría Machado) (Cardona: 27).

Hay, entonces, efectos subjetivos: satisfacción y tranquilidad, armonía y libertad interiores, madurez, experiencia... O, por el contrario: inquietud, avaricia, nerviosismo, insomnio... y todo lo que incluye el sindrome del triunfador: que lleva a un derrumbamiento físico y psíquico prematuro de la persona (Frankl: 126).

h) Su "quietividad". Naturalmente, el "éxito" del éxito, por su naturaleza positiva, estriba, en primer término, en el incremento de los bienes subjetivos: sabiduría y virtud, reconocimiento y estimación, amistad y amor. Por eso, pretender el éxito supone movimiento; el éxito es motivo: motus ad finem. $\mathrm{Y}$ el fin de todo movimiento es el reposo, el sosiego, la quietud. Por lo tanto, el éxito debe ser "quietivo" - para usar términos de Schopenhauer-. Debe aquietar, con la quietud, no de la 
inacción, sino de la paz que propicia eso que se llama contemplación, que es sabiduría: estar-señala Heráclito- con el oído atento al ser de las cosas. Quietud que conduce a la sabiduría práctica o prudencia, que no es mera cautela para anticipar la práctica inteligente, sino para saborear, de la mejor forma, de lo justo y lo bello, del bien y la verdad, del trabajo y el descanso, de la soledad y la compañía. Saber significa que tiene sabor, que se puede saborear, que es sabroso. Por eso se habla de los frutos sabrosos de la sabiduría; saber y sabor pertenecen, así, a la misma familia lingüistica. De modo que la contemplación que debe llegar con el éxito es, en cuanto capacidad de mirar amando (Yepes), la raíz más profunda de la amistad y del amor, que es la mejor forma de relacionarse con los demás. Amor, no el caricaturizado que ordinariamente se nos presenta, sino amor humano que es, sobre todo, convicción intelectual, decisión volitiva y donación afectiva, por eso se alza al terreno de la ética, y por eso exige fidelidad, permanencia, congruencia. Es el amor que se vuelve elevación, expansión, desinterés, plenitud:

Muchas de las cosas que son más importantes para mí, en mi vida concreta, no se pueden medir ni tienen directa traducción económica: una música, un amigo, el recuerdo de una tarde en que creí ser feliz. (...) No estoy haciendo "literatura" sino mencionando cosas que son tan reales como la cotización de bolsa o la tabla periódica de los elementos y que, para mi vida concreta, son mucho más importantes... La literatura no sirve para nada concreto, para nada que se pueda medir o definir con exactitud. Pertenece al ramo perfectamente inútil de las Bellas Artes, como un cuadro de Picasso o una sinfonía de Malher. Para los sectores más inquietos, conviene hacer notar que la literatura no mejora la condición de los pueblos subdesarrollados ni elimina del mundo la opresión o la injusticia, al menos de un modo inmediato y directo (D’Ors, Apud: Ibáñez-Martín: 102).

Por fortuna conocemos casos -ni pocos ni muchos, sólo suficientes- que nos absuelven de lirismo, sostienen nuestro 
optimismo y nos vacunan contra ciertas consejas. Una es la que afirma que: En este picaro mundo no bay persona bonrada que pueda ser un triunfador. La otra indica que: En el éxito, los amigos son fingidos y los enemigos reales.

i) Su deliberación. Un acto, para ser considerado acto humano, debe ser deliberado; es decir: que proceda de una voluntad libre. La posibilidad de conocer el fin, elegir los medios y los modos de actuación, y de prever las consecuencias, nos hace responsables de ese acto. Se nos puede imputar porque lo hemos querido; llevamos en ello mérito o culpa. El éxito, en cuanto acto humano, debe ser deliberado y, por lo mismo, implica responsabilidad moral. Cuando ha sido conseguido de modo corrupto, indebido o ilegal, es razonable que sea enjuiciado negativamente y el «sujeto exitoso" también. Igualmente y con toda razón, la sensibilidad contemporánea impugna el éxito que se alcanza agotando temprana e imprudentemente los recursos naturales, así como el que se ostenta afrentosamente ante la miseria ajena a la que no se procura socorrer.

La deliberación es un acto de la razón práctica (o prudencia) que sopesa las distintas posibilidades o caminos para llegar a lo querido; es una reflexión acerca de los medios idóneos para lograr el fin. En la deliberación, la razón inquiere, investiga, aporta datos, los pondera, escucha consejos... En los procesos de toma de decisiones, la deliberación constituye un paso determinante. Hay, sin embargo, personas que no se toman el tiempo ni la molestia de deliberar; deciden sin reflexionar. Otros deliberan demasiado o con demasiada lentitud, incluso tratándose de decisiones de poca importancia.

La deliberación permite, en un tiempo razonable, comprender una situación dada, asimilar mejor las experiencias propias y ajenas, pre-sentir los acontecimientos, penetrar las motivaciones de otros, sacar de los fracasos nuevas luces... Aclara la inteligencia para comparar situaciones por sus semejanzas y diferencias, fortalece la confianza en el propio juicio 
y, al mismo tiempo, desarrolla la docilidad para oír la opinión ajena (Kriekemans: 22).

Todo esto quiere decir que el éxito sólo está a la altura de la dignidad humana cuando el hombre lo realiza deliberadamente, porque quiere, por algún motivo, por alcanzar una determinada meta y porque en su conquista emplea a fondo todas sus facultades. Ésta es una verdad universal: hacemos algo porque buscamos algo que consideramos bueno, ya que el objeto propio del deseo humano (de la voluntad) es el bien.

Cuando nos sorprendemos a nosotros mismos preguntándonos por qué hemos hecho algo y no encontramos respuesta clara y suficiente, nos preocupamos con razón y, si la cosa se agrava, visitamos al médico, pues un hombre que no sabe por qué hace lo que hace, está enfermo (Farell, 45).

El "éxito" indeliberado, el que cae repentinamente, porque sí, sin deseo ni búsqueda deliberada, en realidad no es éxito: ganar el premio mayor de la lotería, un negocio ventajoso a causa de una inexplicable subida de la Bolsa, el advenimiento de una gran masa hereditaria... Sea todo ello muy bien venido, pero no son éxitos. Son, eso sí, feliz contingencia, golpe de suerte, afortunada imprevisión, dichosa coincidencia... Es lo que se llama "síndrome de los Beverly Ricos" creador de "nuevos ricos" (como aquella nueva rica que buscaba marido que hiciera juego con el mobiliario).

j) Su trascendencia. Antes dijimos que el éxito y los bienes que acarrea, se ordenan a la plenitud de vida. Plenitud -añadimos ahora- que arraiga en lo más íntimo y elevado del hombre y se subordina al amor, acto supremo de la libertad y gracias al cual nuestra intimidad no es sólo conocida y amada, sino también amante y dadora: tener a quién amar y amarle efectivamente hasta hacerle feliz (Yepes).

Por eso se dice que lo máximamente meritorio del éxito, consiste en que el triunfador logre colocarse por encima del 
mismo. Se trata de poseer el éxito, no de ser poseído por él. Uno es esclavo de lo que lo domina (Pe. 2a $, 2,19$ ). El éxito real, cuajado, es el que produce, en la persona del triunfador, un efecto perfectivo y liberador; lo vuelve generoso, lo libera del estrecho utilitarismo y de la miopía del profesionalismo y termina por empapar de alegría la vida toda del triunfador. Y la alegría, como todo lo bueno, es contagiosa: el bien es de suyo difusivo. Así es, según se dice, la plenitud de vida: se prueba en la capacidad de compartir, de administrar generosamente los bienes obtenidos. Es negarse al ego, no por la negación misma, sino por hacer una afirmación mayor. Es, volvemos al principio, la afirmación del amor que desecha el miedo o, al menos, la desconfianza. Es el éxito que se vuelve amor porque -según la precisa definición aristotélica-amor es procurar el bien del otro.

Que el hombre es un ser capaz de dar, quiere decir que se realiza como persona cuando extrae algo de su intimidad y lo entrega a otra persona como valioso, y ésta lo recibe como suya. En esto consiste el uso de la voluntad que llamaremos amor (Yepes: 83).

Se comprende que no siempre sea fácil aceptar estos planteamientos, dado el paganismo contemporáneo regido por la obsesión de buscar y acrecentar los bienes materiales a toda costa, y dada también la fuerza centrípeta que actúa en la naturaleza humana: todo lo de fuera hacia mí, que es el camino del egoísmo que empuja a la persona:

(...) con toda su incondicionalidad de ideas y convicciones, a capitular ante la realidad, pero la realidad mala: ante lo que "todos" dicen o piensan, lo que quiere el término medio; a sucumbir a la falsa experiencia, al éxito aparente, y ya sólo pregunte por el provecho y el placer... Entonces surge ese hombre que a todo el que se esfuerza y espera de veras le dice que hay que ser "realista", que hay que tomar la vida como es, que hay que ver cómo se puede uno abrir paso, hacerse una posición 
ventajosa y disfrutar lo que se ha de disfrutar, etcétera (Hanna Arendt: 81).

Pero, por fortuna, actúa también, en la naturaleza humana, una fuerza centrifuga: de mi hacia fuera, que es el camino del amor. Con palabras de Kierkegaard podemos decir que: la puerta del éxito verdadero se abre hacia fuera, y a quien intenta "derribarla" se le cierra con llave. Porque los bienes, aunque sean subjetivos, por su propia índole trascienden la subjetividad. Existen bienes que no se pueden compartir, sólo se pueden repartir y hay bienes que se pueden compartir porque pueden ser disfrutados simultáneamente por dos o más personas.

A éstos últimos pertenecen los valores morales que residen en lo que se llama ethos: carácter. sinceridad, lealtad, honradez, fidelidad, amistad... y todos aquellos que dan al hombre su contextura moral. En el repartir o compartir, las fuerzas centrífuga y centrípeta se equilibran; el hombre da, sin perder; o, mejor dicho, gana al dar. Del repartir y compartir el gozo del éxito y los bienes que trae consigo, nace el deseo de seguir compartiendo, porque el bien es de suyo difusivo: tiende a comunicarse. Visto así, el éxito consiste en hacer rendir los bienes y en dar, y dar con alegría. Megalopsychos -alma grande - se llamaba, en la antigua Paideia, al triunfador capaz de administrar inteligente, justa y generosamente sus riquezas. Es lo que Descartes llama générosité; Emerson, self-reliance y Aristóteles, magnanimidad: alma grande, espiritu elevado, corazón generoso. Lo contrario es pusilanimidad: pequeñez de espiritu, corazón apocado, alma pequeña: "almita", o peor, almeja. Y, según Jardiel: En el cielo no hay almejas.

Cuando queremos dar algo a quien amamos, que sea la mejor manzana, el libro más bello, las horas mejores del día, el mejor lugar en la oración. ¡Demos algo precioso, no tristes despojos! Creo que fue San Bernardo quien dijo esta admirable sentencia: "la medida de un alma es la grandeza de su amor". Será tan grande 
como lo sea su amor. La exactitud de esta medida la experimentamos siempre que tenemos algo precioso en nuestras manos y, como sopesándolo, nos decimos: “isi tuviera que darlo?»... (Guardini, 35).

Quizá en la respuesta a la pregunta anterior habría que buscar la verdadera clave del éxito. Un fajo de billetes en la bolsa-según se dice-, hace la diferencia entre un día maravilloso, lleno de generosas satisfacciones, y un día aciago, lleno de egoístas remordimientos. La respuesta generosa vacuna al triunfador contra actitudes patológicas de envidia, resentimiento, odio a la vida, no poder soportar en los demás el éxito, incluso de no poder soportar el propio éxito. Es decir: lo que se llama el "síndrome de Narciso" ${ }^{20}$, del que quiere conservarse y conservar sus bienes y sus dotes para sí mismo, pertenecerse sólo a sí, y termina por hacerse insoportable para sí, constatando que el yo es un compañero que no satisface y que nunca se satisface.

\section{EN TORNO A LA NOCIÓN DE «PARADIGMA»}

En lo que llevamos dicho, hemos empleado intencional y reiteradamente la expresión paradigma del éxito. Cabe ahora, después de echar una ojeada a la fenomenología del éxito, preguntar: ¿es legítimo, con propósito educativo, recurrir a paradigmas? Y, más en concreto: ¿es lícito recurrir al paradigma del éxito?

Tal parece que, según los testimonios de la historia, la presencia del paradigma o modelo en materia educativa es universal y constante. Ya Herbart señalaba que la positividad

\footnotetext{
${ }^{20}$ ¿Se acuerda del mítico Narciso, poseedor de muchas dotes que lo hacían sentir un joven exitoso: inteligente, rico, esbelto, fuerte, sano, de viril belleza..? Despreciaba a los que lo buscaban, se negó a todo compromiso. Poco a poco fue quedando sin amigos, sólo la ninfa Eco, enamorada de él, insistente, le llamaba con dulce voz: "Ven, ven". Él, arrogante, le contestó: "De ningún modo. Prefiero morir antes que darte poder sobre mí". Al oír esta respuesta, Némesis, la diosa de la justa venganza, sentenció: "Éste que no ama a nadie, que se enamore de sí mismo". Y así vivió, solo, ensimismado, teniéndose a sí mismo como única compañía.
} 
de la educación no consiste sólo en dejar florecer ciertas pretendidas disposiciones intimas, sino que proporciona al educando experiencias y modelos concretos, y esmeradamente seleccionados de tal modo que ayuden a forjar su personalidad (Abbagnano: 490).

En efecto: el modelo o paradigma educativo ha sido visto como una causa ejemplar que invita al educando a tender, con un esfuerzo ininterrumpido, a la forma más alta de existencia bumana (Göethe). No siempre se ha empleado la expresión paradigma del éxito, quizá porque puede parecer redundante: toda auténtica educación consiste en pasar de un estado a otro más perfecto; o en suscitar el máximo desarrollo integral de la persona. Es decir: son, a mi modo de ver, distintas formas de referirse al éxito, en su significación más genuina, radical y completa, sin nombrarlo. O no se habla del éxito, tal vez, porque pudiera sonar a trivialidad. Después de todo, aprender las tablas de multiplicar, las reglas para uso correcto del gerundio, llenar una plana de caligrafía o resolver un crucigrama son, a veces, verdaderos triunfos; o quizá porque las palabras éxito y triunfo no siempre resultan atrayentes:

¿Qué es triunfar? -se pregunta la escritora Carmen Castro- ¿Pasar por encima de otros, de diez, de veinte o de mil personas? Para mí lo importante es ejercer la profesión con honestidad, lo mejor que pueda... En la profesión se vive fracasando y recomenzando con nuevos bríos (Eguibar: 168).

No sé si he triunfado o no -afirma el pedagogo Adolfo Mállo-; nos limitamos a luchar, porque vivere militare est"; pero la victoria sólo Dios sabe si la hemos merecido. Gloriarse de haber triunfado se me antoja el peor de los "triunfalismos". Cada cual sólo puede hablar, honestamente de "su lucha", que nunca debe ser floja... procurar siempre estar al día en cuanto al conocimiento de los problemas profesionales; trabajar con entusiasmo y entrega, convencido de que se tiene una gran responsabilidad; afanarse en ser justo, evitando tanto el rigor excesivo como el compadrazgo cómplice; permitir -llegado el caso- que la inflexibilidad de la justicia ceda ante una misericordia hecha de comprensión y de amor (Ibid: 64). Vivimos en una sociedad sombría. Medrar: tal es la enseñanza 
que gota a gota cae de la corrupción a plomo sobre nosotros (...) Dicho sea de paso, el éxito puede ser una cosa bastante fea. Su falso parecido con el mérito engaña de tal forma que para la multitud, el triunfo tiene casi el mismo rostro que la virtud. El éxito es compañero del talento (...) Pero, en nuestros días (...) medrar es la clave. Quien medra es venerado: gana el premio mayor de la lotería y serás talentoso. Sé orgulloso y te creerán grande (...) La admiración contemporánea es miope: se toma el similior por el oro: no importa que seas advenedizo, con tal de que llegues primero. El vulgo es un viejo Narciso que se adora a sí mismo y que aplaude todo lo vulgar. Que un merolico se transforme en diputado; que un falso Corneille llegue a dramaturgo; que un eunuco llegue a tener un harén; que un charlatán se vuelva predicador; que un buhonero se case con la usura y tenga con ella siete u ocho millones de francos... no importa: los hombres a todo eso llaman Genio (Adaptado de: Víctor Hugo. Los Miserables. I, 12).

\section{FUNCIÓN METÓDICA DEL «PARADIGMA» O «MODELO»}

Para revisar la legitimidad del paradigma del éxito, consideremos primero que, para la epistemología contemporánea, el paradigma o modelo, tiene una clara función metódica.

Un paradigma (para/deigma: parádeigma) es un modelo (modelus: modo, medida) ${ }^{21}$, empleado como recurso metodológico que permite nuevas explicaciones, favoreciendo así el progreso científico y técnico ${ }^{22}$. En Investigación Operativa, un modelo es un conjunto que representa otro conjunto.

${ }^{21}$ En este escrito emplearé indistintamente ambos términos.

${ }^{22}$ Esta utilidad del paradigma como instrumento heurístico, matriz disciplinar y modelo ejemplar, fue reconocida no hace mucho tiempo por Kuhn (La estructura de las revoluciones científicas, 1962/1971). Para él -señala Hernández Rojasson estructuras conformadas por cinco tipos de componentes definitorios, a saber: a) problemática o espacio de problemas de investigación; b) fundamentos epistemológicos; c) supuestos teóricos; d) prescripciones o propuestas metodológicas y; e) proyecciones de aplicación. Estos enfoques teóricos prevalecientes en psicología, se constituyen en paradigmas porque reúnen comunidades que trabajan en torno a ellos, con ciertos criterios epistemológicos, teóricos y metodológicos propios. Para Hernández Rojas, la proliferación de paradigmas (la pluriparadigmaticidad) propia de la psicología (por las peculiaridades de su objeto de estudio y por la existencia de tradiciones de investigación consolidadas), lejos de provocar cierto estado de inmadurez, en cierto modo resulta benéfica para su propio desarrollo como disciplina. (Hernández Gerardo. Los paradigmas en la psicología de la educación, Paidós, México, 2002, p.62). 
La posibilidad de representación está basada en el isomorfismo de los dos conjuntos. En general, el paradigma designa una representación simplificada y analógica de determinados fenómenos (por ejemplo, modelo de átomo planetario, modelo ondulatorio, etcétera).

En la antropología cultural, el paradigma denota un conjunto de conductas establecidas, provocadas o sancionadas por un grupo o subgrupo social que configura y vincula a sus miembros (por ejemplo, modelo de mujer ejecutiva, de familia, de hombre exitoso, de líder triunfador...). Esto hace que, por su misma naturaleza, un paradigma tienda a ser una configuración reductiva y cerrada de la realidad. Por eso, al menos para la Pedagogía, ningún paradigma es completo, estático y definitivo. De ahí que la visualización del paradigma no signifique la reproducción mecánica del mismo. Para mayor claridad, el trabajo pedagógico establece la distinción entre un modelo educativo y un modelo pedagógico. El primero, más próximo a la idea de ejemplo, se entiende como:

- paradigma, modelo o causa ejemplar que, en la práctica educativa y con propósito didáctico, señala un camino a seguir, una meta a alcanzar;

- prototipo que sirve de inspiración, aliento y guía hacia donde conviene orientar los esfuerzos que exige la educación de la persona; o

- trazos de un perfil empleado en la educación para tratar de que éste se verifique (por ejemplo, cualidades encarnadas en las figuras de héroes, santos, científicos, atletas, artistas..., o cuando se habla del perfil del participante en tal programa formativo; o perfil del egresado de equis facultad...).

El modelo educativo busca facilitar, a nivel intelectual, volitivo y emotivo-afectivo, el pasaje histórico de los valores (entendidos objetiva y subjetivamente), de manera que se conviertan en principios de comportamiento para el educando y en instrumentos de continuidad histórica para el grupo. Es un recurso metodológico que ejemplifica, personifica u os- 
tenta una acción, un oficio, una cualidad o una empresa que, por su valor intrínseco, es digno de ser imitado.

No es un troquel al que haya de ajustarse exactamente la personalidad en formación. El hombre, por fortuna, no se limita a reproducir paradigmas, sino que los interpreta, elige o rechaza: los jerarquiza. Los prototipos influyen en la probabilidad de que se efectúen determinadas conductas gracias a su función predictiva y optativa, no porque se vinculen automáticamente a las respuestas. Pretender lo contrario - hormar una personalidad- sería tan aberrante como el proceder del mítico Procusto, el Estirador, quien tenía una cama de hierro en la que, después de invitarlos a cenar, ataba a los viajeros que tenían la desgracia de caer en sus manos. Si eran más cortos que la cama, les estiraba las piernas hasta que llegaban a la misma medida; si eran más largos, les cortaba un trozo (una vez derrotado por Teseo, Procusto recibió el mismo tormento que él había infligido a otros).

En cambio, el modelo pedagógico, más próximo a la idea de teoría, se entiende como:

- término de confrontación o comparación, empleado en teoría pedagógica con propósito heurístico;

- matriz o forma descriptiva y detallada de una situación, área o sistema, que sirve a la inteligencia humana para operar con mayor orden o con mayor facilidad (modelo idealista, modelo psicoanalítico, modelo clásico, modelo tecnológico...; o bien: modelo icónico, analógico o simbólico).

\section{EL «PARADIGMA EDUCATIVO"}

Siempre se ha considerado que el éxito de la educación (mientras no se reduzca a escolaridad, ni a técnica de la enseñanza) consiste en promover la conciencia de la justa jerarquía de los todos los valores (junto a lo individual, lo social; junto a lo material, lo espiritual; junto a lo inmanente, lo trascendente), y la firme disposición de adecuar la existencia entera a esta jerarquía. Este éxito queda enmarcado por una idea empírica de lo que el hombre es (terminus a quo o 
punto de partida), y por una idea preconcebida (paradigma, modelo o causa ejemplar) de lo que debe y puede llegar a ser (terminus ad quem o punto de llegada). El proceso educativo viene a ser, entonces, una acción racional finalizada que intenta ayudar al hombre a pasar del ser dado al ser pleno. El éxito del hombre consiste en realizar, con toda la dignidad contenida en su humanidad, ese paso.

Ya en la Paideia según Aristóteles: «hay un contraste -señala MacIntyre- entre "el-hombre-tal-como-es" y "el-hombre-talcomo-podría-ser-si-realizara-su-naturaleza-esencial" (Wanjiru:57). La libertad moral del hombre consiste justamente en salvar ese contraste. Contraste que va de "la comprensión de sí mismo" (self-interpretation) a la "realización de sí mismo" (selfactualization) (Frankl:14).

Se explica, entonces, que la Pedagogía, una vez reconocida la significación del paradigma como categoría fundamental de vida y de pensamiento, se haya visto en la necesidad y en la posibilidad de describir casi la totalidad de los sistemas educativos, a lo largo de la historia, a partir de paradigmas o arquetipos que manifiestan el sentido, contenido y meta de la educación ${ }^{23}$. Pero, al parecer, también se ha encontrado con la necesidad de poner de relieve que, en el orden natural y

\footnotetext{
${ }^{23}$ A este respecto, casi la totalidad de los "modelos pedagógicos", se han estructurado a partir de una causa ejemplar como modelo para explicar la acción educativa. Siguen conservando un profundo sentido pedagógico el kiun-tsé (hombre superior) de Confucio; el gurú (maestro del espíritu) de la tradición hindú; el escriba (sabio, letrado, de éxito asegurado en los cuadros burocráticos del faraón). Un amplio apartado merecen los paradigmáticos héroes homéricos, representativos de la areté, como fuerza perfectiva de la virtud más alta: Aquiles, Agamenón, Patroclo, Héctor, Ulises...; Elena, Andrómaca, Hécuba, Electra... Otro tanto habría que decir del hoplita espartano (soldado de infantería, merecedor del inigualable honor de morir por su patria); del kalokagathós (ideal humano estético-ético de la paideia griega); los patriarcas y profetas del pueblo hebreo; del bomo imago Dei de San Agustín; la Leta, modelo de educación femenina de San Jerónimo; del orador de la humanitas latina; del gentleman de Locke o del Emilio de Rousseau... No se pueden olvidar los modelos familiares, sociales y religiosos propuestos por Pestalozzi; las Vidas Paralelas de Plutarco, llenan de impulsos juveniles basados en modelos heroicos y en propuestas de grandeza que constituyen un conjunto importante de ofertas que la educación muestra al educando.
} 
antes de recurrir a un paradigma ajeno, el mejor paradigma educativo para cada uno, es uno mismo: el si-mismo-ideal.

Ya en sus Píticas, Píndaro sentencia: Deviene lo que eres y Sé tal como has aprendido a conocerte. Expresiones que nos recuerdan el Sé el que eres, entendido como: expresa tu dignidad o, sé como debes ser del Eclesiástico, y que pueden ser consideradas como la esencia del más próximo y accesible paradigma educativo, interpretado y reinterpretado innumerables veces. Desde el: No busques fuera de ti, de San Agustín; el ¡Volvamos a nuestro interior! de Rousseau; el Vuélvete lo que eres de Göethe; o el jSé lo que eres mediante lo que haces tuyo!, de Jaspers; hasta el Let it be de Lennon. El éxito del hombre -podemos decir parafraseando a Hannah Arendt- consiste precisamente en la valentía de ser uno mismo: la propia persona, en sus circunstancias y con su responsabilidad.

En el orden natural, y sin que esto se oponga al empleo de otros modelos paradigmáticos, el sí mismo mejorado es el paradigma educativo antonomásico de cada hombre, el que debe mostrarle la imagen más alta del propio ser, de la propia dignidad y de la propia capacidad. Ser-yo significa precisamente tener un camino que lleve desde el Yo de la situación inicial al Yo de la plenitud. En cambio, renunciar al rango que le fija la propia dignidad, es fracaso, es pereza, acedia, mediocridad, que es la desesperación de la debilidad, de la que dijo Kierkegaard que consiste en que uno desesperadamente no quiere ser él mismo (Pieper: 41).

Esto significa que no me puedo explicar a mí mismo, ni demostrarme, sino que tengo que aceptarme. Y la claridad y valentía de esa aceptación constituye el fundamento de toda existencia. [Se trata] de situarse como persona en libertad y responsabilidad; obtener un juicio propio sobre el mundo y una situación propia en él; llegar a ser "Yo mismo", para recorrer también el camino hacia los demás, pudiendo decir "tú" en cuanto que es "yo". Ése es el principio y fin de toda sabiduría. La renuncia a la soberbia. La fidelidad a lo real. La limpieza de la decisión de ser uno mismo y, por tanto, la raíz del carácter (Guardini: 25, 27). 
No es, pues, el paradigma, una invitación a ver hacia fuera, a volverse extraño para sí mismo, a enajenarse. Todo lo contrario, el paradigma contrasta y estimula el verdadero yo del hombre, ante el cual no debe nunca quedarse atrás. Las típicas preguntas que se hacen al niño: ¿qué vas a ser de grande?; o al adulto: ¿qué te gustaría que dijeran de ti en tu panegírico mortuorio?, muestran la necesidad y posibilidad que el hombre tiene de visualizarse idealmente a futuro, de diseñar un yo-ideal ${ }^{24}$ que, como paradigma educativo, pueda convertirse en la más enérgica llamada a intentar el cultivo terco de uno mismo... ¡hasta lograrlo! (D'Ors).

Conviene hacer notar que, aunque de alguna manera la idea del yo-mismo-mejorado como paradigma educativo, también queda contenida en el no busques fuera de ti de San Agustín y en el ;Volvamos a nuestro interior! de Rousseau, según dijimos antes, entre ambos pensadores existen profundas diferencias. En el caso del ginebrino, tal paradigma deviene en inmanentismo (subjetivismo, solipsismo). En cambio, el obispo de Hipona sabe, por experiencia propia y ajena, que es en el ego (en especial, me atrevo a añadir, el ego inflado por el éxito: el ego del triunfador), como interioridad cerrada, narcisistamente ensimismada y volcada hacia sí misma, donde acecha un gran peligro: la tentación que para el hombre constituye su propio yo. Amor propio que ha sido tentación y anhelo de todo bumanismo radical por el que el hombre desea convertirse en principio de sí mismo, en ordenador y dueño de sí mismo, aspirando, según la fuerte expresión agustiniana, a reinar sobre sí mismo: sobre su alma y sobre su cuerpo.

Por eso el hombre agustiniano, si quiere salvar el escollo del inmanentismo, del egoísmo inmovilista, está obligado a trascenderse: trascende te ipsum, a dejarse atraer al orden sobrenatural. Y desde ahí, antes de recurrir a cualquier otro

\footnotetext{
${ }^{24}$ Esto tiene, además, una doble ventaja desde el punto de vista educativo: se evita comparar y "etiquetar" al educando lo cual resulta, generalmente, incómodo e ineficaz.
} 
modelo humano, trascenderse en Jesucristo, como modelo de vida, criterio y norma de conducta, cuyo diálogo trasciende el plano de la comunicación docente para instalarse en el plano de una trascendencia existencial decisiva (Galino: 343).

\section{LA «PEDAGOGÍA DEL ÉXITO»}

Por otra parte, es evidente que el campo de la enseñanza siempre ha sido apto para la proliferación de panaceas pedagógicas: fórmulas mágicas que pretenden garantizar el más amplio y mejor aprendizaje con la mínima inversión de esfuerzo, tiempo y dinero, como preparación para una vida exitosa: útil, patriótica y feliz.

Este empeño es el que llevó a Ratke (1571-1635), por ejemplo, a comprometerse a: Enseñar a cualquiera y a la edad que fuese, en muy poco tiempo, el hebreo, el griego, el latín y otras lenguas; con su realismo educativo, quiso brindar un camino agradable, breve y justo que sustituyera el camino largo, tortuoso y falso de la didáctica anterior (Morando:176). Y Comenio (1592-1670), por medio de su arte de enseñar todo a todos, se propuso la elaboración de una pansofía capaz de abarcar toda clase de conocimientos, y de asegurar-afirmaba- el progreso moral, intelectual y espiritual del hombre y de toda la sociedad; su ilusión era proponer un método con el que los que enseñan, enseñen menos y los que estudian aprendan más; que en las escuelas haya menos alboroto, menos desgana, menos trabajo inútil, y más recogimiento, más diversión y más sólido provecho (Morando: 177). Por su parte, Basedow (1724-1790), anunciaba así su Philantropinum: Enviad a vuestros hijos a disfrutar una vida juvenil, feliz, con estudios agradables coronados por el éxito...

Podríamos entresacar mil ejemplos más, pero hemos de referirnos, ahora, a la panacea que enarbola el éxito como eje en torno al cual gira la educación, vista como cantera de triunfadores: la llamada pedagogía del éxito. 
El éxito, entendido como resultado y motivación de signo positivo que, por los efectos satisfactorios que produce en el alumno, estimula sus facultades y suscita actitudes propicias para emprender proyectos audaces, asumir retos, superar dificultades y sostener un esfuerzo intenso y proficuo, siempre ha sido visto por la Pedagogía como base firme de toda metodología didáctica para asegurar un mayor rendimiento académico y, más tarde, profesional.

Sin embargo, la llamada pedagogía del éxito, al proceder como suelen hacerlo todas las panaceas, aísla un elemento (el éxito) y lo exagera hasta convertirlo en único y excluyente. Es así como cualquier elemento, técnica, estrategia o método, en sí válidos y útiles, pasa a convertirse en una filosofía de la vida, si no es que una religión. Por eso el éxito -junto con su resultado: el placer - se ha llegado a ver como el eje y sentido de la existencia humana; fundamento de toda axiología; causa, contenido y consecuencia de toda educación; criterio empírico para valorar al hombre y su calidad de vida, y norma para estratificar la sociedad. Tratando de seguir la evolución de esta pedagogía del éxito, podemos condensarla así:

El éxito como instrumento de aprendizaje. Según el experimentalismo de E.L. Thorndike (1874-1949) y otros autores, una respuesta acompañada de resultados satisfactorios se fija más que otra que da resultados adversos. De donde el placer y el éxito son factores favorables, mejor dicho, determinantes primordiales del aprendizaje, según tal teoría. De su labor de experimentación ${ }^{25}$, Thorndike derivó un par de leyes del aprendizaje: la ley del ejercicio y la ley del efecto.

La primera ley, también llamada ley de la formación del bábito, se refiere al afianzamiento de conexiones entre estímulo

\footnotetext{
${ }^{25}$ Recuérdese que Thorndike realizó un trabajo ímprobo con pollos, peces, gatos, perros, simios, etcétera, a los que instaló en ingeniosas construcciones: cajas problemas, laberintos de complicación diversa, jaulas, pasadizos, trampas y otros aparatos. Parte del experimento consistía en recompensar o castigar a los sujetos, según se comportaran en la prueba, con alimento o choques eléctricos.
} 
y respuesta (E-R) mediante la práctica o ejercicio. En cambio, dichas conexiones se debilitan por la falta de dicho ejercicio, o llegan a extinguirse por el desuso.

La ley del efecto, por su parte, establece que cuando una respuesta, o grupo de respuestas a un estímulo, produce un efecto exitoso y, por consiguiente, un estado placentero en el sujeto, se fortalecen tales conexiones. Por el contrario, éstas se debilitan si el efecto es desagradable o frustrante.

Todo acto que en una situación dada produce satisfacción, se asocia con esa situación, de modo que cuando la situación se reproduce, la probabilidad de una repetición del acto es mayor que antes. A la inversa, todo acto que en una situación dada produce displacer se desliga de la situación, de modo que cuando la situación se repite, la probabilidad de repetición del acto es menor que antes (Thorndike: 203).

Esto pretende comprobar que el estímulo de la alabanza por los éxitos en el aprendizaje, es más constructivo que la actitud contraria. Se afirma, dentro de esta ley, que de manera inmodificable, la respuesta a un estímulo queda reforzada si se obtiene el premio. Esto explica, según Thorndike, todos los procesos del aprendizaje (aprendizaje por ensayo y error) y, por lo mismo, la conducta total del hombre. En esta misma línea se han desarrollado las sucesivas investigaciones de Skinner, que ha puesto en el refuerzo provocado por la respuesta de efecto gratificante, el factor fundamental de aprendizaje, y que basándose en tal criterio ha sabido reproducir en el laboratorio, incluso con animales de modesta capacidad (por ejemplo, pichones), comportamientos adquiridos, notablemente complejos ${ }^{26}$. Aun así, Hernández Ruiz considera que en definitiva: 
La ley del ejercicio no añade nada especial a cuanto había establecido la tradición psicopedagógica sobre el fortalecimiento y desaparición de ciertos hábitos y habilidades, físicos o mentales, debido a la ausencia o repetición de los actos que los fomentan o inhiben. Y señala, además, que la ley del efecto pretende elevar el deleite a condición de principio. "Principio trasnochado", como indica Valenzuela, con oportunidad notoria; pero además, principio falso de toda falsedad, pues rara será la persona que no pueda afirmar por experiencia propia que un error o un fracaso le enseñaron más que cien aciertos. "De los escarmentados salen los avisados", dice el refrán, y a él nos atenemos, no como regla de conducta pedagógica, pues todos los extremos son viciosos, pero sí como advertencia más racional que el estulto edenismo que nos quiere presentar la realidad como un camino de rosas (Hernández: 23).

El éxito como fundamento de la teoría de los fines. Esta versión tiene en el pragmatismo de John Dewey (1859-1952) y su escuela, su mayor exponente. Según esto, la educación: (learning by doing), es una reconstrucción continua de la experiencia; un crecimiento que se ha de entender en sentido

\footnotetext{
${ }^{26}$ No es posible señalar aquí la enorme influencia del conexionismo (o asociacionismo) y sus contribuciones, así como las críticas de que ha sido objeto. Baste señalar, entre las críticas, su carácter elementalista y el peligro que supone el traslado hacia lo humano y sin matices, de las conclusiones con animales; el conductismo mecanicista al que conduce y que niega el valor universal de los principios lógicos y metafísicos, base de toda esencia; la circularidad de sus leyes que vendrían a decir: Si un animal aprende cuando su conducta es seguida por un estado de cosas dado, aprenderá cuando su conducta sea seguida de este estado de cosas; su énfasis en la sensación como causa única de la presencia de nuevos elementos en la conciencia, lo cual limita el conocimiento al ámbito barrido por el sentidos y otorga un carácter fortuito al aprendizaje; y la automaticidad del fortalecimiento que supuestamente ocurre y que haría imposible dominar a voluntad los pensamientos. La asociación, en efecto, explica la presencia de nuevos elementos de pensamiento, pero es la voluntad la que los conserva o los rechaza, gobernando así el curso del pensamiento en el estado de vigilia. En cambio, Thorndike cré́a que el aprendizaje podía darse independientemente de que hubiera alguna conciencia de lo que y por qué se estaba aprendiendo. Por último, recuérdese que desde el punto de vista ético, se ha señalado que este determinismo mecanicista termina por minar los valores humanos.
} 
cronológico y en su dinamismo interno. Crecimiento significa, para Dewey, capacidad del individuo de insertarse convenientemente en una sociedad en perpetuo cambio. El interés humano estimula todo esfuerzo por alcanzar un fin; la investigación científica es una actividad intelectual impulsada por la vida; pensar es resolver problemas; experimentar es verificar. El éxito empírico es el que funda la verdad de las hipótesis.

La educación es de la experiencia, en la experiencia y por la experiencia. El éxito o el fracaso educativos vienen dados por el grado de consecución de los resultados de cada experiencia. La conducta es satisfactoria, buena y recta solamente a la luz de los resultados previstos, es decir, del éxito obtenido. El mundo, la sociedad y el hombre mismo están en constante cambio; también los intereses, valores y propósitos de los hombres cambian: un hombre bien alimentado, prefiere la música a la comida; pero si tiene hambre, prefiere la comida a la música ${ }^{27}$.

Este criterio utilitarista, aplicado a toda actividad humana (educación, arte, ciencia, moral, religión, etcétera), la reduce a juicios subjetivos de valor, cuya verdad y utilidad se expresan en el éxito en la solución de problemas; la utilidad es, pues, el fundamento del valor. Se determina así, utilitariamente, lo

\footnotetext{
${ }^{27}$ Este pragmatismo (modalidad del relativismo) busca la "verdad" del proceso cognoscitivo en el fin que debe conseguirse con él. Si un conocimiento es útil para tal fin, si resulta útil para la acción, es "verdadero", concuerde o no con la realidad. Desde esta perspectiva relativista, los valores no se abstraen del pensamiento, sino que surgen de la utilidad práctica: dependen de cada experiencia y sus resultados, placenteros (exitosos) o frustrantes (fracaso). Con esta instrumentalización del conocimiento, el pragmatismo deja de ser una metodología para saltar al orden metafísico y convertirse en una teoría de la verdad y de la realidad: la verdad se reduce a utilidad y la realidad a espíritu. En educación, uno de los grandes intereses de Dewey, su "filosofía operacional" se orienta a formar al hombre eficiente, útil para una sociedad democrática. Sus ideas y sugerencias en este campo han sido muy estimadas. Propugna una educación activa, basada en la cooperación entre educandos y educadores, y capaz de promover formas de actividad concreta y útil, porque así adquiere la conciencia de sus límites y de sus posibilidades para obtener nuevos y superiores éxitos (Urdanoz, 1988: 259).
} 
que es el bien moral, como ideal empírico dotado de permanencia, como las leyes científicas son "aserciones garantizadas" y, por lo tanto, relativamente durables; y se determina quién es el hombre útil y valioso. Así pues, el éxito se postula, no sólo como medio y fin del aprendizaje, sino como fundamento del bien, del valor y de toda acción humana. Es decir: se erige en el eje de la existencia.

Naturalmente, este énfasis exagerado en el éxito técnicoutilitario como principal fundamento -si no es que el únicodel aprendizaje, de la ciencia y de la moral, no podía dejar de provocar reacciones adversas. Hernández Ruiz señala que:

Aunque se pudiera demostrar que eso que se viene llamando "éxito en la vida" es el móvil único o fundamental de todos los hombres, y por consecuencia la finalidad específica de la educación, por nuestra parte nos limitaríamos a lamentarlo, y a renunciar, de ser aceptado universalmente un hecho de semejante naturaleza como norma de conducta educativa y social, a toda actividad pedagógica, pues entenderíamos que para tal resultado no merece la pena ni es digno educar. Allá cada cual con su suerte en el ring en que se pretende convertir la sociedad humana... Eso que se llama éxito en la vida, o es una frase vacía, o es la miseria moral y filosófica más grande que ha producido la mente humana, sin que valga para destruir la exactitud de este juicio la incuestionable integridad y el alto nivel de conducta de muchos de sus sostenedores teóricos (Hernández Ruiz: 23).

En efecto: si el éxito en la vida significa estar en constante pugna con los demás por ser y mantenerse como el número uno en fama, poder y riqueza, es decir: estar en una situación individual ventajosa en contraste con otras situaciones individualmente inferiores, el éxito resulta incompatible con una concepción social. Sólo el individuo lo vive (porque, ¿a quién se le va a ocurrir medir su éxito en la vida con relación a la de los pájaros o los ahuehuetes?). Hernández Ruiz añade:

Como ordinariamente se le entiende, el "éxito" es impensable como fenómeno universal y, por lo tanto, impensable como fin de 
una educación humanista y solidaria, concebida como igualdad de derecho y de oportunidad para todos los hombres. No lo es así, desde luego, entre nosotros; pero creo que ni en el país donde la doctrina se engendró y se propagó, a causa, quizá, del momento de prodigiosa prosperidad material que vive, en virtud de la favorabilísima coyuntura económica por la que atraviesa, que tal es la causa fundamental, sin desdén para las cualidades del pueblo que la disfruta... Ahora bien, podemos pensar la "pedagogía del éxito", para impedir que se nos salga al paso con la imputación de que extremamos las cosas, como una pedagogía que aspira a crear en el hombre la capacidad de llevar a buen término lo que se proponga. En ese caso es una pedagogía teleológicamente inane pues su valor depende de los propósitos que la persona conciba: si los propósitos son buenos, la educación es buena; si los propósitos son malos, la educación es mala (Hernández: 24).

Tratando de salvar esta situación, habría que pensar que la expresión pedagogía del éxito se refiere a una educación tal que la persona que la reciba sólo considere como éxito, el buen término de buenos propósitos y la perfección en actividades socialmente eficaces $y$ moralmente válidas Entonces el éxito se confunde con el bien y desaparece como concepto independiente. La pedagogía del éxito, en cuanto tal, se reduce a la nada.

Pero no estamos en trance de ocultar ni velar la verdad. Y la verdad pura, desnuda, cruel, es que eso que llaman éxito en la vida generalmente se mide, en los ejemplares aptos para ser tomados como exponentes, por el número de cadáveres que se deja en el camino. Dictadores de pueblos previamente arrasados y aniquilados, o dictadores de precios o de modas. ¿Qué más da? (Hernández: 24).

Añadiríamos, con Malaparte que: Con una filosofía meramente pragmatista, utilitarista, bedonista y actualista, es muy dificil que el "triunfador" convenza a nadie a que vaya hacia delante, que marche siempre hacia el frente y que se exponga a entregar su vida por un ideal. 


\section{EL «ÉXITO» EN EL TRABAJO PEDAGÓGICO}

Como fácilmente se comprende, a pesar de los juicios anteriores, sería absurdo pretender la proscripción del éxito, como noción o como fenómeno, en el quehacer educativo. Pero también resultaría absurdo pretender su mitificación. Se trata, más bien, de verlo en toda su amplitud, fijar su ubicación, subrayar su valor educativo y redimir su significado. Implícita o explícitamente, el paradigma del éxito tiene y siempre ha tenido, según dijimos, gran importancia y utilización en la teoría pedagógica y en la práctica educativa.

Como motivación y como refuerzo, el éxito halla su fundamento más firme en las tendencias de la naturaleza humana. Tendencias que se expresan como necesidad y tienen por objeto, o el desarrollo bio-psíquico, o el desarrollo socio-moral del individuo. En conjunto, apuntan al desarrollo más pleno de la persona. Nos referiremos, en este caso, a la necesidad de fama y de honor. A toda persona -al menos a toda persona sana- le gusta quedar bien, obtener resultados exitosos en aquello que emprende, respetarse y ser respetado. Esto no va, de ninguna manera, en contra de la virtud de la humildad, ya que bumildad es la verdad, según la gran Teresa de Ahumada. La fama y el honor que suelen acompañar al éxito tienen, como orientación natural primaria, el desarrollo de la vida intelectual y moral de la persona.

Conviene puntualizar que, hablando con corrección, fama es la opinión que se tiene comúnmente de una persona. Tal opinión puede ser buena o mala: si la conducta es buena, honesta, aparece manifiesta a los demás, adquiere ante ellos buena fama. Si, por el contrario, es pública su conducta deshonesta, adquiere mala fama. En sentido estricto, la fama propiamente dicha es la buena fama, el buen nombre. Nombradia es tener buena fama, respetar el propio nombre, mantener un nombre respetable. Ignominia, en cambio, es mala fama, nombre deshonrado. Buena fama es buena reputación, credibilidad, prestigio. 
Así como el éxito, como prestigio o buen nombre de una empresa evidencia sus "cualidades" (buen producto, calidad del servicio, confianza que inspira, responsabilidad ética...), así el éxito habrá de evidenciar la buena fama y cualidades del triunfador.

La fama -como el éxito- puede ser ordinaria o extraordinaria. La primera es la común que corresponde a todo hombre, siempre. La segunda se refiere a determinadas personas por razón de sus excepcionales hazañas o cualidades (santidad, heroicidad, sabiduría, genialidad, arte, destreza, bondad, etcétera).

Lo normal es que el éxito venga acompañado de honor (reconocimiento, honra o respeto), que es el testimonio de la buena fama de la persona de éxito. El honor es un signo exterior, manifestativo de la alta consideración y estima que alguien nos merece. Mediante el honor testificamos la excelencia ajena. Se manifiesta por medio de palabras (alabanzas, agradecimientos, felicitaciones, vítores...); hechos (festejos, saludos, desfiles, coronaciones, reverencias, aplausos, homenajes...); o cosas (dinero, premios, estatuas, dando su nombre a una calle...).

A diferencia del honor, el éxito y la fama, no requieren del reconocimiento público. Es suficiente el testimonio sincero de la propia conciencia y la satisfacción de haber obrado bien; pero ante los demás, algunas veces se requieren signos exteriores ${ }^{28}$.

${ }^{28}$ Recuérdese, por ejemplo, que Rousseau -según su propio testimonio-, prescindiendo de toda alteridad se ve como él quiere verse; es bueno porque así se ve; asumiendo atribuciones quasi divinas, se autocrea según su propia conciencia: Rousseau es bueno y justo porque así se quiere ver; Rousseau es creación de él mismo. En cambio, los personajes retratados por Plutarco, se conocen a sí mismos en los demás; son buenos y nobles porque sus conciudadanos así lo consideran; son creación de los demás. Otro es el caso de San Agustín: él se conoce en sí mismo y en los demás pero, sobre todo, se conoce en Dios; es como Dios lo ve; quiere conocer a Dios para conocerse a sí mismo porque Agustín es creación de Dios: sólo Dios ve en Agustín lo que ni él mismo ni los demás pueden ver. 
De modo que, debido a su fundamento natural, el derecho a la fama y al honor (o al respeto u honra) que suelen acompañar al éxito, no son privativos de unos cuantos "triunfadores", ni son sólo una estrategia didáctica, sociológica, psicológica o comercial; ni un artificio creado por parlamentos, cámaras o congresos para llevar la fiesta en paz: son un derecho inalienable, inherente a la dignidad de todas y cada una de las personas.

Justamente la educación se fundamenta en la convicción de que el hombre no debe solamente mantenerse en la existencia; sino que debe también abrirse en ella un camino. Cada persona tiene su espacio, su tiempo, su misión. Fama y honor, son su derecho; sacar adelante su vida y cumplir su misión, son su éxito.

\section{EL ÉXITO COMO MOTIVACIÓN}

Como se ha sugerido antes, en la práctica educativa y en el quehacer pedagógico, el paradigma del éxito personal tiene, y siempre ha tenido, una gran importancia como motivación y como refuerzo para el despliegue libre e integral del individuo y, a partir de los individuos, el mayor y más armónico desarrollo de la cultura y la sociedad.

Como motivación intelectual, intrínseca al proceso de aprender, el éxito surge como resultado de la curiosidad natural del hombre y de sus predisposiciones personales para la exploración y conquista de su mundo. Las motivaciones -ya lo dijimos- se particularizan con mayor eficacia en cuanto contenido, dirección y expresión, como resultado de un ejercicio exitoso y como anticipación de consecuencias satisfactorias. En un principio, la realidad aparece ante el niño de modo confuso e inconsistente. El presente, el dato, toda la existencia tienen necesidad de ser integrados en un orden de verdad y de valor, es decir, ser comprendidos, razonados y justificados (Madinier:15). Reflexionar bien, exige observar bien. En estas tareas, que tienen gran valor en la elaboración 
de proyectos y que hacen la vida del espíritu excepcionalmente fecunda, el éxito es aliado eficaz para despertar, aplicar y reforzar disposiciones apropiadas en el educando. Quien reflexiona bien antes de obrar, tiene mayores probabilidades de éxito. Gracias al deseo de saber y a la capacidad para conocer objetivamente, el hombre puede intercalar la reflexión entre la observación y la realización exitosa. Esto es lo que desde siempre se ha llamado sabiduria práctica o prudencia (ahora se le llama proactividad).

A partir de estas convicciones, la psicopedagogía ha desarrollado, innumerables tests y otros instrumentos para el control de los resultados exitosos en la adquisición de conocimientos y experiencias ${ }^{29}$. Este control permite, a su vez, diseñar actividades específicas tendientes a ayudar a los alumnos a desarrollar hábitos intelectuales de observación, experimentación, reflexión, lectura inteligente, disposición para el estudio: concentración, retención, relación... Los progresos evidentes, los resultados exitosos y hasta los fracasos momentáneos, estimulan al alumno a superar con éxito los obstáculos que naturalmente se presentan en el trabajo académico.

Como motivación social y profesional. Parece ser que el éxito, como motivación social consiste, en definitiva, en amar la profesión y servir, con libertad, a través de ese modo de amar. En este renglón, el éxito (aceptación, estima, respeto...)

\footnotetext{
${ }^{29}$ Están, también, muy desarrolladas las pruebas del éxito, que ayudan al control personal del aprendizaje, no necesariamente de forma comparativa ni competitiva. Se distinguen de los tests corrientes de aprovechamiento escolar, porque no comparan el rendimiento del alumno con el rendimiento medio de una población mayor, ni determinan si los rendimientos de dicho alumno se distinguen del rendimiento medio, ni en qué grado. Su objetivo consiste en calibrar el rendimiento de un alumno en relación con una meta de aprendizaje descrita de forma personal y operacional. La meta es, por tanto, una descripción lo más exacta posible de lo que un alumno sabe en un sector determinado, como también de lo que no sabe. La comparabilidad con otros es algo secundario, lo que importa es suministrar la información necesaria para decidir la ayuda que necesita un determinado alumno para que pueda participar con éxito en la enseñanza planificada.
} 
es determinante como incentivo para un comportamiento social auténtico. Esto implica, primero, dar cauce espontáneo a las tendencias pre-sociales: necesidad de vivir en compañía, espíritu gregario y gusto por la aventura y lo sensacional, participación en la vida comunitaria como expresión de la actividad instintiva de goce, juego y lucha. (Lo que también lo hacen los animales). En el caso del hombre, se trata de dar cauce inteligente y libre al despliegue de las tendencias propiamente sociales. Unas, ligadas al yo: deseo de hacerse valer, de merecer la consideración social. Otras, referidas a los demás: preocupación y contribución al bienestar del prójimo: familia, amigos, vecinos, comunidad...; interés por la instauración efectiva de la concordia; colaboración solidaria, comprensión y respeto; empeño efectivo por la paz y la justicia en todos los ámbitos de la sociedad entera.

Pero, dada la paradójica condición de la naturaleza humana (tendencia natural al bien y aversión natural al esfuerzo), ni las tendencias naturales ni los buenos deseos bastan. Se requiere la intervención de la educación social, capaz de estimular con hábitos volitivos, orientar con hábitos intelectuales y festinar con hábitos afectivos, la realización de tales tendencias. Esto exige aprendizaje, paciencia y disciplina que, coronados por el éxito, más fácilmente pueden incrementar en el alumno: espíritu de servicio, deseo de superación personal constante, afán de logro y aptitud para saber elegir ocupación, oficio o carrera. Esto redunda en una sana ambición por crecer en prestigio profesional, en influencia político-cultural y status social que favorezca la realización personal, familiar, profesional y social del individuo. Todo esto ayuda a la persona a ser mejor, para servir mejor.

Como motivación volitiva y emotivo-afectiva. Según un parecer muy generalizado, el éxito no suele estar en un objetivo fácilmente alcanzable, cómodo. Es, más bien, el resultado de un esfuerzo inteligente y sostenido por alcanzar una meta ambiciosa o realizar un proyecto arduo conquistados día a 
día. Exige talento, poco o mucho, pero bien trabajado. Esto solamente lo logra una voluntad educada, disciplinada y muy identificada con el objetivo; abnegada y capaz de enamorarse de cualquier cosa pequeña o grande relacionada con el ideal. Esto es lo que se entiende por afectividad inteligente, o inteligencia emocional capaz de sostener horas de trabajo comprobadas, de renunciar al romanticismo. Es, pedagógicamente hablando, el éxito educativo que se convierte en principio de comportamiento para la persona y en instrumento de cohesión, fuerza y continuidad en los grupos a los que pertenece. Sus valores típicos son: aventura, riesgo, entusiasmo...; seriedad, que evita la huida hacia lo exótico, frívolo o bohemio en nombre de la creatividad y permite, en cambio, asumir con libertad y adecuación las obligaciones del deber y del oficio.

Como motivación moral, el éxito puede verse como la impronta que deja en nosotros el vivir de acuerdo a nuestra condición de seres humanos. Es decir: el éxito puede verse como un estilo de vida. Estilo que se evidencia en las obras de cada uno. Y es, de nuestro espíritu, de donde manan, como de su fuente, nuestras acciones. Por eso se afirma que educar el estilo es educar el espíritu. Lo mismo habría que decir con respecto al éxito: educar para el éxito es, en primer lugar, educar el espíritu. Dicho de otra forma: una educación para el éxito debe dirigirse, en primer término, a caracterizar un ethos, un modo de conducta sana, recta, fuerte y a desarrollar una cultura profesional; a desarrollar un estilo propio de ser y de actuar; y a despertar lo que se llama conciencia profesional, caracterizada, principalmente, por: una idea verdadera y completa de ser humano; comprensión del carácter social del hombre y su trabajo; suficiente preparación profesional; recta formación moral; compromiso deontológico; fidelidad a la obligación de trabajar; superación personal y profesional constante; virtudes profesionales tales como: honestidad, lealtad, apertura, servicio; aspiración a la excelencia... 
Si la educación es, en su forma más perfecta, la realización de uno mismo, sólo es posible donde la conciencia moral es activa. Quien ha alcanzado la madurez humana se preocupa durante toda su vida por ordenar sus tendencias o, lo que es igual, de hacer justicia a todos los valores y de hacerlos fructificar.

\section{«ÉXITO», FAMILIA Y ESCUELA}

La globalización de la cultura, la disolución del entorno socio-cultural y los cambios acelerados que suceden a nuestro alrededor, han traído consecuencias que nos afectan a todos. Esto ha hecho más difícil que, sobre todo la generación más joven, desarrolle una identidad estable. En esa coyuntura, se ha observado que la familia, al ver erosionada su influencia sobre los hijos, y algunos sistemas escolares, con su insistencia excesiva en una educación para el cambio, han ayudando a agudizar, en muchos jóvenes, el fenómeno de desconcierto que Maslow (1970) llama identidad instantánea, causante, en gran parte, de la llamada generación equis, o generación light. Pseudoidentidad determinada por fenómenos superficiales tales como la moda en el vestir, pensar, opinar, actuar, todo lo cual interfiere con el desarrollo de un compromiso social, profesional y moral estable y serio.

El mismo autor señala, entre las necesidades básicas para el desarrollo de una identidad más estable y sana, el sentimiento de seguridad, de pertenecer, de ser aceptado en comunidades con suficiente firmeza. Es claro, entonces, que la familia -primera instancia de identidad y de identificación-, y la escuela -que debe seguir siendo una continuación del hogar- deben reasumir el papel decisivo en la educación que les corresponde y al que habían renunciado o habían delegado.

Son muy numerosos los estudios que se han hecho acerca de la relación paradigma-sujeto y, más en concreto, de las relaciones padres-hijos. Como en cualquier otro aprendizaje, los primeros alientos y actitudes que los jóvenes desarrollen ante 
el éxito, en gran parte los aprenden por observación, imitación, experiencia directa y educación. Es decir: lo aprenden en su hogar y en las escuelas a las que asisten.

Según la opinión de un buen número de jóvenes entrevistados: el comportamiento de los educadores puede constituir un paradigma formativo a los ojos del educando, sobre todo por tratarse de una asociación frecuente que, si es gratificante, por generalización, pueda ser asociada a todo comportamiento semejante. En la misma línea, opinan que un paradigma más cordial y simpático es más imitado que otro más distante y antipático. El status del modelo también posee una gran influencia en la imitación (competencia, "categoría", prestigio social, profesional, económico; cualidades personales...; sobre todo: afán de logro y de superación), de modo que son más imitados los modelos de más alto y mejor status.

Recientes trabajos pedagógicos concluyen que el concepto moral de éxito que se formen los jóvenes queda, en gran parte, determinado por las experiencias y las expectativas de sus educadores. Hay educadores que procuran ampliar la noción de éxito de modo tal que no se centre únicamente en lo material, mientras que otros cargan las tintas sobre la necesidad de tener éxito en la vida, centrando su atención en lo económico. Con frecuencia se inculca a los jóvenes la mentalidad de "ganar dinero" desde muy temprana edad. Se alienta al niño para que trabaje de forma retribuida siempre que se presente la ocasión. El paradigma del self-made man -el hombre que se ha hecho a sí mismo- sigue constituyendo un modelo que pasa de generación en generación. Se ha encontrado que:

Con frecuencia, los hijos de "ricos", recriminan a sus padres al verlos esclavos del engranaje de los negocios o de las exigencias sociales: acosados por el miedo de perder lo que tienen o por la avidez de aumentarlo, acaban por no gozar siquiera de lo que tienen. Por su parte, los hijos de "pobres", envidian el confort de los ricos y recriminan a sus padres por 
su incapacidad de darles lo que desean. Otros padres sólo pueden dar unos pocos bienes materiales adquiridos con gran esfuerzo y sin lograr satisfacer a sus hijos. En estos casos, en los que la dinámica familiar gira en torno a un "modelo" según el cual los bienes materiales son lo único que importa, que son el fin, no sólo un medio, ni padres ni hijos viven felices.

En otro sentido, son innumerables los jóvenes que reconocen que los principales valores y actitudes vitales y profesionales para "salir adelante con dignidad en la vida y en el trabajo" (que esto es tener éxito), los han aprendido del ejemplo de sus padres: confianza en sí mismo; fidelidad, justicia y competencia; puntualidad, orden y aprovechamiento del tiempo; fortaleza para no perder la serenidad en las dificultades; pensar en grande y pensar bien; emprender, con honor y dignidad, aventuras arriesgadas; prudencia, para ver los fines y elegir los medios; ayudar, desinteresadamente y hasta en cosas pequeñas, a sus hermanos, compañeros y amigos; a no sucumbir al fracaso; caridad y cordialidad con el contrincante... Sorprendentemente, esta idea acerca de la influencia de la familia, cada vez encuentra mayor justificación científica en las más recientes conclusiones de la teoría empresarial actual, según la cual: hay valores profesionales que, o se arraigan en el hogar desde la infancia, o no acaban de arraigarse nunca.

Por su parte, los centros de enseñanza también están en excelentes condiciones de formar cualidades personales y de enseñar los conocimientos que necesitarán los futuros profesionales para realizar, exitosamente, su vocación personal y ayudar a que la sociedad también cumpla su vocación.

En la dinámica universitaria, son cada vez más los alumnos que evidentemente mejoran su desempeño académico con la idea de, posteriormente, acceder a ocupaciones laborales que les garanticen un mejor nivel profesional, mayor prestigio social y mejores ingresos y satisfacciones. Crece, también, en popularidad, la idea de que quienes obtienen las mejores notas en la universidad son, generalmente, los que 
ocupan los puestos de mayor responsabilidad. Es, también, evidente que los alumnos graduados con distinciones académicas, y con estudios posteriores, son más solicitados por empresas de mayor prestigio e influencia. Numerosas investigaciones demuestran que existe una correlación bastante elevada entre las calificaciones del alumno y su éxito profesional posterior.

En la actualidad, muchas empresas, al buscar un dirigente, conceden mayor peso al crédito que otorga el haber estudiado en una escuela o universidad determinadas que a cualquier prueba de capacidad intelectual. Para la contratación y promoción de personal, así como la asignación de puestos y sueldos, se toma muy en cuenta la procedencia de los candidatos: si provienen o no de escuelas que incentiven la búsqueda del éxito profesional y social por medio de la competencia técnica y del compromiso ético.

En la labor de asesoría con profesores y alumnos universitarios, hemos encontrado que, casi en su totalidad, ambos grupos coinciden en la necesidad de que cada centro educativo, junto a una enseñanza de gran calidad, cree un ambiente de estudio, trabajo y amistad que ayude a desarrollar más decididamente:

- gusto por la vocación; afición por el estudio y por la reflexión en cuanto a su responsabilidad universitaria;

- habilidad para saber hacer propias las grandes ideas, de modo que se asuman con hondura, se elaboren interiormente hasta llegar a convicciones profundas y puedan ser transmitidas a otros llenas de viveza intelectual y vital, con la fuerza de lo pensado y lo vivido;

- comprensión y exigencia por una formación cultural: técnica y humanista de gran calidad, así como el desarrollo de profundas y sinceras aspiraciones humanas;

- madurez de criterio, que permita entender la trascendencia de la vida de cada uno y responder con altura a los problemas que plantea el entorno; 
- congruencia y unidad de vida, de donde se derivan la buena reputación y la credibilidad;

- convicción de que las cualidades que definen al alumno, definirán, más tarde, al profesional. Afán de destacar profesionalmente. Evitar el barniz sin bondura;

- clima profesional de grandes ideales y aspiraciones: personales, profesionales, sociales; económicas, culturales, espirituales;

- agudo, alto, pero específico, sano y constructivo pensamiento crítico, que lleve a actuar de acuerdo a los resultados de la crítica;

- carácter firme para saber superar el ambiente, que a veces invita a la vanagloria, frivolidad o a la bohemia;

- capacidad de reacción, a fin de no acostumbrarse al mal y a no pactar con la mediocridad;

- comprensión de que la calidad de una institución, está determinada por las personas que la integran: su prestancia, el comportamiento, la indumentaria, los modales, los hábitos personales... definen, por lo menos en parte, el cuidado y respeto que cada uno tiene por su propia persona y por los demás;

- criterio para distinguir entre el auténtico mérito del falso éxito.

Es decir, en definitiva, todos buscan -buscamos- comprender la realidad de que triunfar en la vida, llevarla a buen término, es una tarea complicada. Las cosas pueden salir bien o mal, podemos tener éxito o fracasar. El fracaso es la no realización de los ideales y la interrupción o abandono de la tarea, su frustración. Por eso el fracaso es doloroso... El éxito y el fracaso pueden ser algo muy relativo, y ser libre ante ellos presupone una aceptación previa de uno mismo, de la situación que nos ha tocado vivir, de la tarea que hemos emprendido y, por consiguiente, de las limitaciones ajenas a nuestra voluntad en que continuamente nos vemos sumidos... Quien se ríe de su fracaso, se libera de él, porque deja de tomárselo en serio, e incluso lo convierte en algo 
cómico, mientras continúa adelante, con mayor ímpetu... Lo específico de la vida humana no es sólo emitir respuestas, sino tener propuestas, proyectos vitales, ideales, que nos rescaten de nuestros propios fracasos y nos impidan quedar anegados en el dolor. En suma: coherencia, libertad y madurez, y no quedarse paralizado por el fracaso es lo que ayuda al logro de la felicidad (Cfr. Yepes: 451s).

Parece ser que, desde el punto de vista formativo, tanto el éxito como el fracaso ayudan al triunfador a mantener la cabeza bien metida en el cielo y los pies bien firmes en la tierra. Es decir: le ayudan a ser humilde y, además, discreto. Confucio le diría: No te creas tan grande que te parezcan los demás pequeños. Y Brentano añadiría: Ojalá te pudiéramos decir: jtienes un callar, que se escucha con el alma! 


\section{REFERENCIAS BIBLIOGRÁFICAS}

ARENDT, Hannah., Arendt., México., Paidós., 1999.

BERMOnT, Hubert., Cómo Ser un Consultor de Éxito., Argentina., Vergara., 1989.

BIDDLE, Bruce J. et al., La enseñanza y los profesores (III)., Barcelona., Paidós., 2000.

BOWEN, James., Teorías de la educación., México., Limusa., 1995.

CARDONA, Carlos., Ética del quehacer educativo., Madrid., Rialp., 1990.

D'ORS, Eugenio., Aprendizaje y Heroísmo., Pamplona., EUNSA., 1973.

EGUIBAR, Mercedes, et al., ¿Qué voy a ser?., Madrid., Rialp., 1973. FARELL, Walter., Guía de la Suma Teológica., Madrid., Anzos., 1988. FLORES D'ARCAIS, Giuseppe, et al., Diccionario de Ciencia de la Educación., Madrid., Paulinas., 1990.

FRANKL, Viktor E., La psicoterapia al alcance de todos., Barcelona., Herder., 1992.

GALINDO GARCÍA, Ángel., La pregunta por la Ética., Salamanca., Universidad de Salamanca., 1993.

GALINO, Ma. Ángeles., Historia de la educación., Madrid., Gredos., 1988.

GARCía GUAL, Carlos., Mitos: Platón., Madrid., Siruela., 1998. GAUQUELIN, Michel y Françoise., El mecanismo de la persuasión., Bilbao., Mensajero., s/d.

GONZÁLEZ, Mariano., Educación y orden familiar., Madrid., EDIMAT., 2002.

GUARDINI, Romano., Cartas sobre autoformación., San Sebastián., Dinor., 1966.

GUARDINI, Romano., La aceptación de sí mismo., Madrid., Cristiandad., 1977.

GUTIÉRREZ RÍOS, Enrique., La Ciencia en la Vida del Hombre., Pamplona., EUNSA., 1975. 
HERNÁNDEZ RUIZ, Santiago., Metodología general de la enseñanza., México., UTEHA., 1980.

IBÁÑEZ-MARTÍN, José A., Hacia una formación humanística., Barcelona., Herder., 1989.

KRIEKEmAnS, A., Pedagogía General., Barcelona., Herder., 1982.

LERMA JASSO, Héctor., ¿Qué tipo de alumno soy?., México., Trillas., 1999.

LERMA JASSO, Héctor., La Subjetividad en Jean-Jacques Rousseau., Pamplona., EUNSA., 2003.

LLOYD, Sam R., Cómo desarrollar la asertividad positiva., México., GEI., 1995.

MORIN, Lucien., Los charlatanes de la nueva pedagogía., Barcelona., Herder., 1975.

MUSGRAVE, P.W., Sociología de la Educación., Barcelona., Herder., 1972.

ORTEGA Y GASSET, José., "Misión de la Universidad", en Revista de Occidente., Madrid., 1968.

OVEjero, Anastasio., Psicología social de la educación., Barcelona., Herder., 1988.

PADILlA, M. R., Héroes Mitológicos., Madrid., EDIMAT., 2002. PIEPER, Josef., El ocio y la vida intelectual., Madrid., Rialp., 1979. SÉNECA., Cartas a Lucilio., México., SEP., 1985.

SCHWARTZ, David J., Pensar en Grande. La Magia del Éxito., México., Herrero., 1992.

SPECK, Josef, et al., Conceptos Fundamentales de Pedagogía., Barcelona., Herder., 1981.

SUETONIO., Los doce césares., México., SEP., 1985.

URDANOZ, Teófilo., Historia de la Filosofia., Madrid., BAC., 1988. VARGAS LLOSA, Mario., La fiesta del Chivo., México., Alfaguara., 1999.

YEPES, Ricardo., Fundamentos de Antropología., Pamplona., EUNSA., 1997. 